\title{
Life cycle environmental impacts of domestic solar water heaters in Turkey: The effect of different climatic regions
}

DOI:

10.1016/j.scitotenv.2017.12.057

\section{Document Version}

Accepted author manuscript

Link to publication record in Manchester Research Explorer

\section{Citation for published version (APA):}

Uctug, F. G., \& Azapagic, A. (2018). Life cycle environmental impacts of domestic solar water heaters in Turkey: The effect of different climatic regions. Science of the Total Environment, 1202-1216.

https://doi.org/10.1016/j.scitotenv.2017.12.057

\section{Published in:}

Science of the Total Environment

\section{Citing this paper}

Please note that where the full-text provided on Manchester Research Explorer is the Author Accepted Manuscript or Proof version this may differ from the final Published version. If citing, it is advised that you check and use the publisher's definitive version.

\section{General rights}

Copyright and moral rights for the publications made accessible in the Research Explorer are retained by the authors and/or other copyright owners and it is a condition of accessing publications that users recognise and abide by the legal requirements associated with these rights.

\section{Takedown policy}

If you believe that this document breaches copyright please refer to the University of Manchester's Takedown Procedures [http://man.ac.uk/04Y6Bo] or contact uml.scholarlycommunications@manchester.ac.uk providing relevant details, so we can investigate your claim.

\section{OPEN ACCESS}




\title{
Life cycle environmental impacts of domestic solar water heaters in Turkey: The effect of different climatic regions
}

\author{
Fehmi Gorkem Uctug $^{1 *}$ and Adisa Azapagic ${ }^{2}$ \\ ${ }^{1}$ Izmir University of Economics, Faculty of Engineering and Computer Science, Sakarya Caddesi \\ No:156 35330 Balcova, Izmir / Turkey \\ ${ }^{2}$ School of Chemical Engineering and Analytical Science, The University of Manchester, The Mill, \\ Oxford Road, Manchester, UK, M13 9PL
}

*Corresponding author: gorkem.uctug@yahoo.com; gorkem.uctug@ieu.edu.tr

\begin{abstract}
Solar water heating (SWH) systems could help reduce environmental impacts from energy use but their performance and impacts depend on the climate. This paper considers how these vary for residential SWH across four different climatic regions in Turkey, ranging from hot to cold climates. Life cycle assessment was used for these purposes. The results suggest that in the hotter regions, the impacts of SWH are 1.5-2 times lower than those of natural gas boilers. A similar trend was observed in the two colder regions except for acidification, which was four times higher than that of the boiler. The raw materials and electricity required for the manufacturing of the systems were found to be the most important contributors to the impacts. Recycling the major components instead of landfilling reduced human toxicity potential by $50 \%$ but had only a small effect $(5 \%)$ on the other impacts. The impacts were highly sensitive to the type of material used for the construction of the hot storage tank, but were not affected by transport and end-of life recycling. The only exception to the latter is human toxicity potential which decreased significantly with greater recycling. Extrapolating the results at the national level showed that SWH systems could reduce the annual greenhouse gas emissions in Turkey by $790 \mathrm{kt} \mathrm{CO}$-eq. and would save the economy $\$ 162.5$ million per year through the avoided imports of natural gas. All other impacts would also be reduced significantly (3-32 times), except for acidification which would double. Therefore, SWH systems should be deployed more extensively in Turkey but government incentives may be needed to stimulate the uptake.
\end{abstract}

Keywords: climatic regions; environmental impact; life cycle assessment; solar water heaters; Turkey.

\section{Introduction}

Buildings are the biggest consumers of energy worldwide, using more than a third of all final energy and half of global electricity (Cao, et al., 2016; IEA, 2013a). In some regions, particularly those in developing countries which are dependent on traditional biomass sources, energy use in buildings represents up to $80 \%$ of total final energy use (IEA, 2013a). The majority of energy used in buildings in China Europe, and the US is due to heating, both space and water (IEA, 2013a). Globally, coal and natural gas are the predominant sources of space and water heating in buildings and are responsible for significant greenhouse gas emissions (Koroneos \& Nanaki, 2012). For instance, $45 \%$ of the $\mathrm{CO}_{2}$ emissions in the US are caused by energy use in buildings (Barnes \& Parrish, 2016).

Different measures can be taken to reduce energy use in buildings. Some examples include using effective insulation materials, applying passive heating design, choosing energy-efficient home 
appliances, and supplying energy from renewable sources (Harvey, 2009). Amongst the renewable energy sources, solar water heaters (SWH) have become globally widespread. A SWH system comprises a solar collector, a storage tank, and pipelines. In most cases, the collector is made of a cylindrical glass tube with a special heat-absorbing coating, coupled with a copper coil that is placed inside the glass tube, through which water flows (Al-Madani, 2006; Jamar, et al., 2016). By the end of 2014, the global installed capacity of SHW was $410.2 \mathrm{GWh}$, corresponding to a total of 586 million $\mathrm{m}^{2}$ of collector area (IEA, 2014). The leading countries in cumulative water collector capacity in operation per 1,000 inhabitants are Austria (419 kWh), Cyprus (412 kWh) and Israel (400 kWh). On a per-capita basis, Turkey is ranked $9^{\text {th }}$ globally with $162 \mathrm{kWh} / 1,000$ inhabitants, but in absolute terms, Turkey is the $3^{\text {rd }}$ largest producer and $2^{\text {nd }}$ largest user of SWH systems worldwide (Altuntop \& Erdemir, 2013).

More than $90 \%$ of Turkey's primary energy demand is supplied by fossil fuels (IEA, 2013b) and only $28.5 \%$ of the primary energy demand is met by local means (Turkyilmaz, 2015). Turkey has very limited oil and natural gas resources, thus she has to import the bulk of these fuels. Almost all (99\%) annual consumption of natural gas and the large majority (89\%) of oil consumption in Turkey are met via imports (Republic of Turkey - Ministry of Foreign Affairs, 2016). The average annual cost of energy imports in Turkey is approximately $\$ 56$ billion (Incecik, 2015). The only considerable local source of conventional energy is lignite; however the general quality of Turkish lignite is very low, with high sulphur and ash contents (Atilgan \& Azapagic, 2015). Hence, minimising the use of fossil fuels is of utmost importance to Turkey, from both socio-economic and environmental points of view.

Turkey has a significant solar energy potential of $380 \mathrm{TWh}$ per annum (Turkyilmaz, 2015). One study (WEC, 2009) revealed that in 17\% of the country (mostly in the Mediterranean and Southeast Anatolia regions in the south), SWH systems can provide $100 \%$ of typical domestic hot water needs. Furthermore, in $94 \%$ of the country, $80 \%$ of domestic hot water needs can be met by SWH systems. Between 1998 and 2009, the output of solar energy in Turkey (excluding electricity from solar photovoltaics (PV)) has increased at an average annual rate of $10 \%$, although the increase has slowed down in the recent years. It is estimated that the total collector area in use in Turkey is approximately 20 million $\mathrm{m}^{2}$ and almost $20 \%$ of the residential buildings in the country have SWH systems installed (Altuntop \& Erdemir, 2013). The contribution of SWH systems to the Turkish economy is estimated to be around $\$ 1$ billion per year. Most of the systems in Turkey are based on flat-plate collectors and gravitational flow systems. The evacuated-tube collector, the most popular SWH type in China, is relatively rare (Altuntop \& Erdemir, 2012).

The performance of SWH systems is dependent on the climate and can vary significantly from region to region, affecting not only their energy output but also their environmental impacts. Several studies considered life cycle impacts of SWH in countries with different climates, including in Greece (Koroneos \& Nanaki, 2012; Tsilingiridis, et al., 2004), France (Lamnatou, et al., 2015), Italy (Ardente, et al., 2005), Switzerland (Simons \& Firth, 2011), the UK (Greening \& Azapagic, 2014), and the US (Hang, et al., 2012). Koroneos and Nanaki (2012) carried out a life cycle assessment (LCA) of a SWH system with electricity used as an auxiliary source of energy in the Greek city of Thessaloniki. The authors estimated the environmental impacts of the manufacturing and assembly of the SWH system and found that acidification and winter smog were the two most significant environmental impacts with the heat storage tank being the main contributor to the overall impacts. In another study in Greece, Tsilingiridis et al. (2004) compared the life cycle environmental impacts of a thermosiphon-type domestic SWH system to those of electrical and gas heating systems. Unlike 
Koroneos and Nanaki, they applied a cradle-to-grave approach to estimating the impacts. Their results showed that copper and steel used to manufacture the system were the main environmental hotspots. They also found that a natural-gas heating system had a lower overall environmental impact when compared to the hybrid solar-electrical system, mainly because of the contribution of electricity rather than solar energy.

In a study of environmental impacts of SWH systems in Corsica, France, Lamnatou et al. (2015) discovered that the parallel configuration of the collectors can significantly improve the environmental performance of the system compared to the series arrangement. The study based in the Italian city of Palermo (Ardente, et al., 2005) considered five different scenarios for electricity supply to a SWH system: medium and low voltage, average Italian mix, regional electricity mix, and average European mix. The SWH system dependent of the Italian electricity mix was found to have the highest environmental impacts.

Simons and Firth (2011) estimated life cycle environmental impacts of supplying the entire thermal energy requirements of an apartment building in Switzerland using water-based sensible heat storage. They found that, with the use of SWH systems, it was possible to reduce the consumption of commercially-sourced primary energy by $84 \%$ to $93 \%$, also reducing $\mathrm{CO}_{2}$ emissions by $59 \%$ to $97 \%$. However, their study also revealed that the impacts of SWH on the ecosystem quality were higher than those of heat pumps and fossil fuel-based systems due to the high abiotic resource depletion. Human health impacts, on the other hand, were found to be similar to those of heat pumps and lower than those of fossil fuel and biomass boilers.

In a UK-based LCA study, Greening and Azapagic (2014) investigated whether domestic SWH systems are an environmentally sustainable option for locations with a relatively low solar radiation. They found that, compared to gas boilers, solar thermal systems were a better option for only five out of 11 environmental impacts considered, with global warming and depletion of fossil resources being lower by $88 \%$ and $83 \%$, respectively. However, other impacts, such as human and ecotoxicity, were up to $85 \%$ higher. The impacts of SWH systems were affected by the need for a backup heating system, typically gas boiler. The authors concluded that for this reason, as well as because of a lack of suitable locations and poor efficiency, the potential of SWH systems to contribute to a more sustainable domestic energy supply in the UK was limited.

Finally, Hang et al. (2012) studied the impacts of flat- and evacuated-plate collectors in three different locations in the US and compared their findings to the impacts from conventional fossil fuel-based boiler systems. They found out that flat-plate SWH systems using natural gas auxiliary heater had the best performance energetically and economically. The only environmental impact they investigated was the global warming potential and the results were highly sensitive to the daily water consumption and collector area.

As far as we are aware, there are no other studies of environmental impacts of SWH in Turkey. To our knowledge, there are only two other studies related to the applications of SWH in Turkey: Benli investigated the potential of solar water heating from domestic applications in Turkey (Benli, 2016) whereas Muneer et al. investigated the potential of solar water heating for Turkish textile industry (Muneer, et al., 2008). However, both of these studies were concerned with determining the potential of solar water heating in Turkey and did not involve any environmental impact analysis.

It is also worth mentioning that solar energy can be used for residential cooling, either coupled with SWH or as an independent system. Several LCA studies of solar cooling systems are available in the 
literature (Longo, et al., 2017; Beccali, et al., 2016; Beccali, et al., 2014; Beccali, et al., 2012; Beccali, et al., 2012; Finocchiaro, et al., 2016). However, as this research focuses on solar water heaters, discussion of solar cooling systems is outside the scope and is not considered further.

In this study, we consider life cycle environmental impacts of obtaining hot water for buildings from SWH systems in four regions in Turkey with different climatic conditions to investigate how these may affect the impacts. The results are compared to the impacts from natural gas boilers, a typical alternative source of domestic heat, as well as to the above-mentioned studies in different countries. The methodological details regarding the study, including the scope, the functional unit, and the assumptions, can be found in the following section.

\section{Methods}

The environmental impacts were estimated using LCA, following the methodological guidelines in the ISO 14040 and ISO 14044 standards (ISO, 2006a; ISO, 2006b). CCaLC LCA software (CCalC, 2016) was used to model the system and estimate the impacts according to the CML 2001 method (Guinee, et al., 2001). The following impacts can be estimated in CCaLC and were considered in this study: global warming potential (GWP), acidification potential (AP), eutrophication potential (EP), photochemical oxidants creation potential (POCP), ozone layer depletion potential (ODP), and human toxicity potential (HTP). In addition, the net energy gain of the SWH systems was also calculated. The next sections describe the goal of the study, system boundaries, the assumptions, and data.

\subsection{Goal and scope definition}

The goals of this study were:

i) to estimate life cycle environmental impacts of supplying domestic hot water to households via a SWH system;

ii) to compare the impacts from the SWH system to those from the most common conventional source of domestic hot water - natural gas boilers; and

iii) to estimate the environmental implications of utilising SWH at the level of the whole country.

Four different climatic regions were chosen to examine the effect on the impacts related to the different heat requirements, which in turn depend on climatic conditions. The selected regions correspond to the four climatic regions in Turkey as follows (see Figure 1):

1. Region 1 is characterised by long, hot summers with plenty of sunshine and warm, rainy winters;

2. Region 2 has hot and moist summers and cold winters, with occasional snowfall;

3. Region 3 is also characterised by hot and arid summers, but much colder winters than Region 2 with plenty of snowfall; and

4. Region 4 has short, cool summers and very long and very cold winters with extreme snowfall.

In each region, the main city was selected as a study location; these were Antalya (Region 1), Istanbul (Region 2), Ankara (Region 3), and Erzurum (Region 4).

The system boundary was from cradle to grave, comprising extraction and production of raw materials for the SWH system, its manufacture, operation, maintenance and end-of-life management. All the transportation steps between these stages were also considered. The functional unit was defined as the 'total energy supplied by the SWH system for the domestic hot water 
requirements of a typical four-person Turkish household over the lifetime of the system'. This size of the household is congruent with the average household size in Turkey of 3.6 people (Anon., 2014). The amount of hot water required for such a household is 100 litres per day at a temperature of $60^{\circ} \mathrm{C}$ (Kokturk, 2008). However, based on the definition of the functional unit, the same SWH system will generate a different amount of hot water in different regions, as detailed further on. The lifetime of the SWH systems was assumed at 25 years (Greening \& Azapagic, 2014).

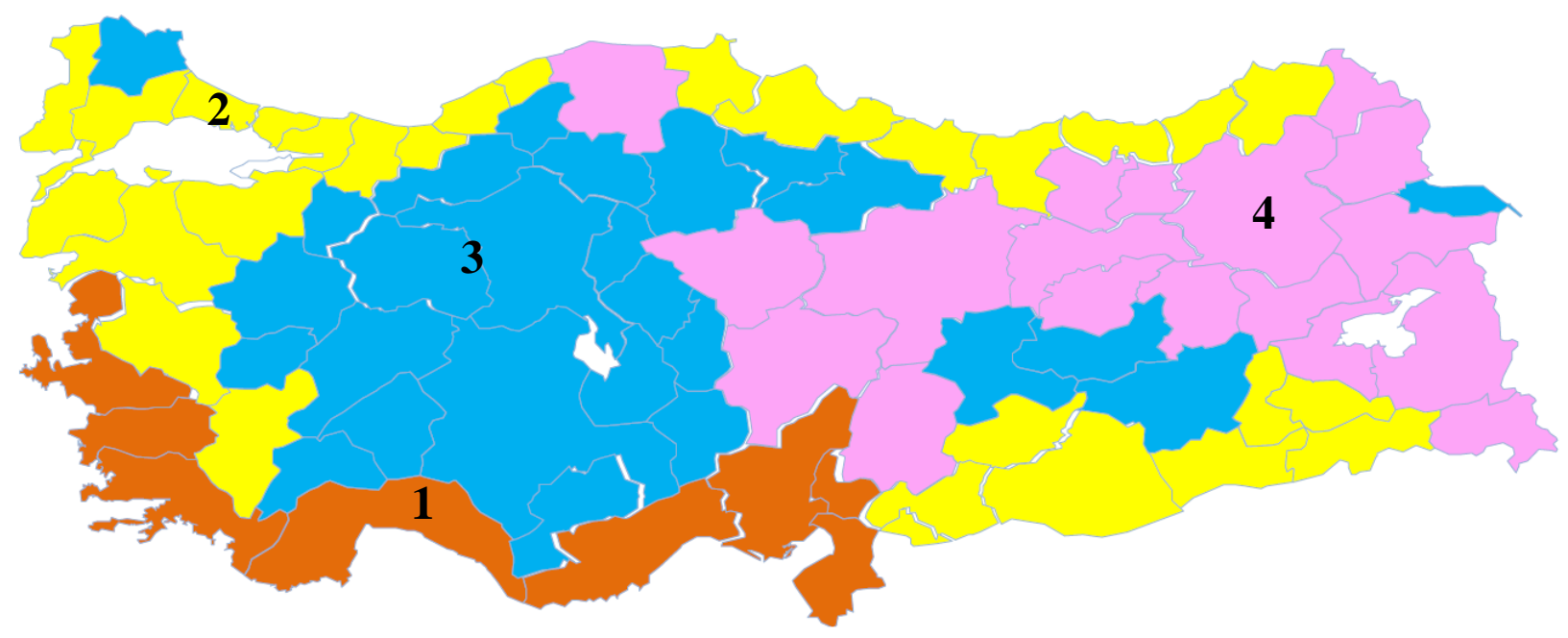

\begin{tabular}{c|c|c|c}
$\begin{array}{c}\text { Climatic region } 1 \\
(\text { Antalya })\end{array}$ & $\begin{array}{c}\text { Climatic region } 2 \\
\text { (Istanbul) }\end{array}$ & $\begin{array}{c}\text { Climatic region } 3 \\
\text { (Ankara) }\end{array}$ & $\begin{array}{c}\text { Climatic region } 4 \\
\text { (Erzurum) }\end{array}$ \\
\hline
\end{tabular}

Figure 1. Climatic regions in Turkey (Ekici, et al., 2012) considered in this work [The position of the numbers in the figure denotes the location of the cities: $1=$ Antalya; $2=$ Istanbul; $3=$ Ankara; $4=$ Erzurum]

\subsection{Inventory data}

\subsubsection{The SWH system}

A flat-plate collector of the thermosiphon-type was considered in this study as such systems occupy the largest market share in Turkey (Altuntop \& Erdemir, 2013). As shown in Figure 2, the system consists of a collector and a hot-water storage tank (HWST). The water is circulated through the system by natural convection, eliminating the need for a pump and minimising the energy input. The collector is mounted on a rooftop, facing south, with a typical area of $2.25 \mathrm{~m}^{2}$ (Demirdöküm, 2013); the HWST volume is 200 litres (Table 1). The water storage capacity was deliberately kept higher than the average daily requirement of the household in order to account for fluctuations in the daily consumption due to seasonal changes. In Regions 3 and 4, a heat exchanger with propylene glycol was added to the system to prevent freezing of the water inside the collector; for the same reason, the amount of the insulation material for the collector and tank was doubled. Propylene glycol was assumed to be replaced every five years (Greening \& Azapagic, 2014; Ardente, et al., 2005) over the 25-year lifetime of the SWH. The same replacement interval was also assumed for the water used as a heat-transfer fluid in the heat exchanger. Electricity required for the operation of the heat exchanger pump was also considered. 
The inventory data for the SWH system, detailed in Table 2, were obtained mainly from a Turkish manufacturer (Demirdöküm, 2013) and their related study on the system's performance (TÜV, 2013); the missing data were supplemented from the literature (Hang, et al., 2012). The environmental impacts of the Turkish electricity mix used in the manufacturing processes were updated from an earlier study (Atilgan \& Azapagic, 2016) using electricity generation data for the year 2015 (Turkyilmaz, 2015). The background data were sourced from Ecoinvent 2.2 (Ecoinvent, 2017).

The transport data are summarised in Table 3. The system is manufactured in the town of Bozüyük in Bilecik province of Turkey (Demirdöküm, 2010). The transportation distances for the major raw materials used in the manufacturing process were determined by identifying the location of the nearest plant where each material is manufactured. For the minor raw materials not listed in Table 3, it was assumed that the manufacturing takes place in the vicinity of Bozüyük, for which transport was not considered.

Table 1. An overview of the SWH system considered in the study

\begin{tabular}{lc}
\hline \multicolumn{1}{c}{ Parameter (unit) } & Value \\
\hline Direction & South \\
Collector type & Flat plate (roof top) \\
Net collector area $\left(\mathrm{m}^{2}\right)$ & 2.25 \\
Storage tank capacity $($ litres) & 200 \\
Hot water temperature $\left({ }^{\circ} \mathrm{C}\right)$ & 60 \\
Average daily water requirement by household (l) & 100 \\
\hline
\end{tabular}

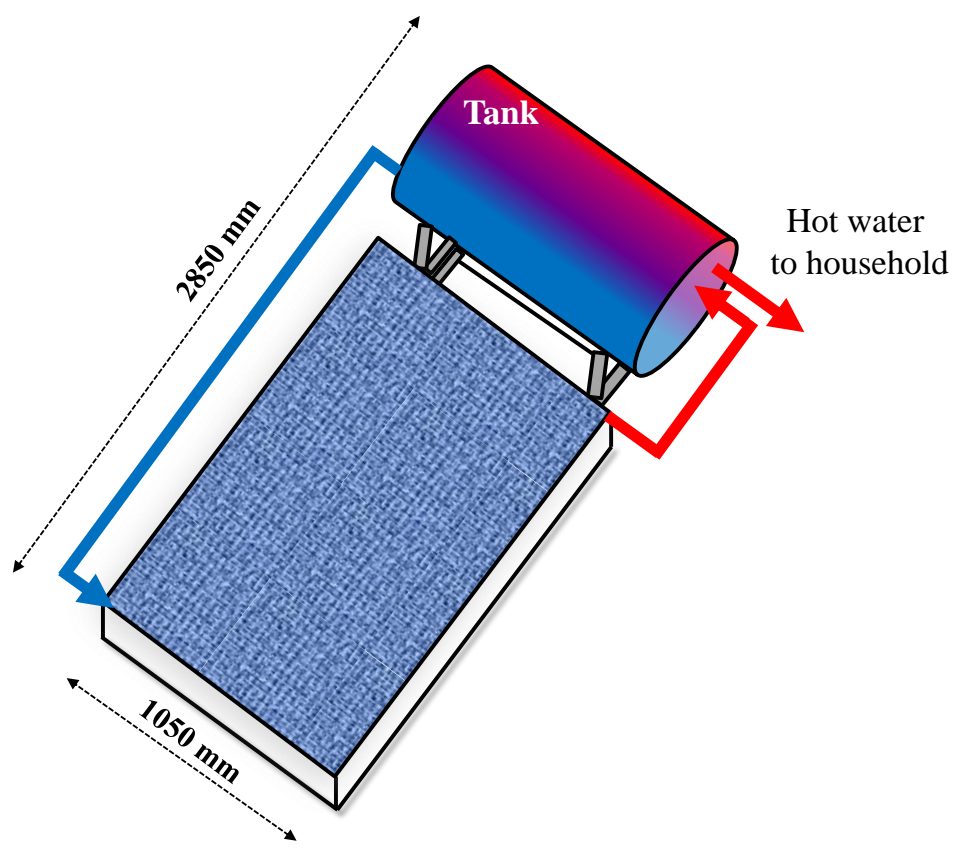

Figure 2. An illustration of the direct thermosiphon solar water heating system 
Table 2. Inventory data for the manufacture and use of the SWH system

\begin{tabular}{|c|c|c|c|}
\hline Stage & Inputs & Amount & Ecoinvent dataset \\
\hline \multicolumn{4}{|l|}{ Manufacture } \\
\hline \multirow[t]{12}{*}{ Collector } & Aluminium $(\text { frame })^{\mathrm{a}}$ & $1.80 \mathrm{~kg}$ & Aluminium production, primary, ingot, global \\
\hline & Steel (piping) ${ }^{\mathrm{a}}$ & $4.14 \mathrm{~kg}$ & Chromium steel, primary, $18 / 8$, at plant \\
\hline & Copper (balance of plant) ${ }^{\mathrm{a}}$ & $2.82 \mathrm{~kg}$ & Copper, at regional storage \\
\hline & Corrugated board for packaging ${ }^{a}$ & $3.68 \mathrm{~kg}$ & $\begin{array}{l}\text { Corrugated board, mixed fibre, single wall, at } \\
\text { plant, Europe }\end{array}$ \\
\hline & Tempered glass (collector) ${ }^{b}$ & $22.5 \mathrm{~kg}$ & $\begin{array}{l}\text { Flat glass (virgin), coated, at plant }{ }^{\mathrm{c}} \text {; flat glass, } \\
\text { tempered }\end{array}$ \\
\hline & Polyurethane foam (insulation) ${ }^{b, d}$ & $2.43(4.86) \mathrm{kg}$ & Polyurethane, flexible foam, at plant \\
\hline & $\begin{array}{l}\text { Propylene glycol (heat } \\
\text { exchanger) }\end{array}$ & $1.19 \mathrm{~kg}$ & Propylene glycol, liquid, at plant \\
\hline & Water (heat exchanger) ${ }^{\mathrm{a}, \mathrm{d}, \mathrm{f}}$ & $1.38 \mathrm{~kg}$ & Water, completely softened, at plant \\
\hline & Water for production processes ${ }^{a}$ & $9.40 \mathrm{~kg}$ & Tap water, at user, RER \\
\hline & Steel (heat exchanger tubes) ${ }^{\mathrm{d}, \mathrm{e}}$ & $15.23 \mathrm{~kg}$ & Chromium steel $18 / 8$, at plant \\
\hline & Steel (heat exchanger pump) ${ }^{\mathrm{d}, \mathrm{h}}$ & $3.00 \mathrm{~kg}$ & Chromium steel $18 / 8$, at plant \\
\hline & $\begin{array}{l}\text { Electricity for the production of the } \\
\text { system }^{\mathrm{a}}\end{array}$ & $4.18 \mathrm{MJ}$ & Turkish electricity mix ${ }^{\mathrm{e}}$ \\
\hline \multirow{6}{*}{ Storage tank } & Steel $(\operatorname{tank})^{b}$ & $79.00 \mathrm{~kg}$ & Steel, low alloyed, at plant \\
\hline & Steel (piping) ${ }^{\mathrm{e}}$ & $7.64 \mathrm{~kg}$ & Stainless steel, hot rolled coil \\
\hline & Bronze (valve) ${ }^{\mathrm{e}}$ & $0.24 \mathrm{~kg}$ & Bronze, at plant \\
\hline & Iron (valve) ${ }^{\mathrm{e}}$ & $0.01 \mathrm{~kg}$ & Cast iron, at plant \\
\hline & Polyurethane foam (insulation) ${ }^{\mathrm{d}, \mathrm{e}}$ & $2.83(5.66) \mathrm{kg}$ & Polyurethane, flexible foam, at plant \\
\hline & Electricity (steel sheet rolling) ) $^{\mathrm{b}, \mathrm{h}}$ & $509.50 \mathrm{MJ}$ & Turkish electricity mix ${ }^{\mathrm{e}}$ \\
\hline \multirow{2}{*}{$\frac{\text { Operation \& }}{\text { maintenance }}$} & Electricity (heat exchanger pump) ${ }^{\mathrm{d}, \mathrm{g}}$ & $5400 \mathrm{MJ}$ & Turkish electricity mix ${ }^{\mathrm{e}}$ \\
\hline & Propylene glycol ${ }^{\mathrm{f}}$ & $4.76 \mathrm{~kg}$ & Propylene glycol, liquid, at plant \\
\hline \multicolumn{4}{|c|}{${ }^{\mathrm{a}}$ Hang et al. (2012). } \\
\hline \multicolumn{4}{|c|}{ b Demirdöküm (2013). } \\
\hline \multirow{3}{*}{\multicolumn{4}{|c|}{$\begin{array}{l}\text { ' Only applies to the landfilling scenario; in the recycling scenario, it was assumed that recycled glass is used. } \\
\text { A heat exchanger was added to the SWH system in Regions } 3 \text { and } 4 \text { and the amount of the insulation material was doubled (values } \\
\text { shown in brackets for the polyurethane foam). }\end{array}$}} \\
\hline & & & \\
\hline & & & \\
\hline \multirow{2}{*}{\multicolumn{4}{|c|}{${ }^{\mathrm{f}}$ The initial am }} \\
\hline \multicolumn{2}{|c|}{$\begin{array}{l}{ }^{g} \text { Lamnatou et al. (2015). } \\
\end{array}$} & & \\
\hline \multicolumn{4}{|c|}{$\begin{array}{l}\text { h } \text { Based on Atilgan \& Azapagic (2016) but updated to the electricity mix in } 2015 \text { (37.9\% natural gas, } 25.7 \% \text { hydroelectricity, } 15.3 \% \\
\text { imported coal, } 12 \% \text { lignite, } 4.5 \% \text { wind, } 1.4 \% \text { anthracite, } 1.3 \% \text { geothermal, } 0.9 \% \text { fuel oil, } 1 \% \text { other). }\end{array}$} \\
\hline
\end{tabular}

Table 3. Transport data for the major raw materials and the SWH system

\begin{tabular}{llllc}
\hline $\begin{array}{l}\text { Material/ } \\
\text { SWH system }\end{array}$ & Origin & Destination & Transport mode $^{\mathbf{a}}$ & $\begin{array}{c}\text { Distance } \\
(\mathbf{k m})\end{array}$ \\
\hline Aluminium & Seydişehir, Konya & Bozüyük & Lorry (>16t) & 397 \\
Steel & Ereğli, Zonguldak (via Ankara) & Bozüyük & Rail freight & 550 \\
Copper & Ereğli, Zonguldak (via Ankara) & Bozüyük & Rail freight & 550 \\
Polyurethane foam & Polatl, Ankara & Bozüyük & Lorry (>16t) & 204 \\
Tempered glass & Gebze, Kocaeli & Bozüyük & Lorry (>16t) & 179 \\
SWH system & Bozüyük & Antalya (Region 1) & Lorry (>16t) & 441 \\
& & Istanbul (Region 2) & Lorry (>16t) & 234 \\
& & Ankara (Region 3) & Lorry (>16t) & 282 \\
\hline
\end{tabular}

${ }^{\mathrm{a}}$ Life cycle inventory data for all transport were sourced from Ecoinvent 2.2. 
For end-of-life treatment, two different scenarios were considered, as specified in Table 4. In the first, all the components were assumed to be landfilled, whereas in the second, the recyclable components (steel and aluminium) were recycled. No information on the recycling of flat glass was found, so instead data for the recycling of glass bottles were used. Furthermore, no information was found on copper recycling which is hence not considered. Although scenarios 1 and 2 may appear similar to a certain extent (see Table 4), when the share of steel and glass within the system is taken into account, whether these two materials are landfilled or recycled could make a significant difference.

The system was credited for the recycling of steel (World Steel Association, 2011) and aluminium (Paraskevas, et al., 2015). In order to identify the maximum possible effect of recycling on the environmental impacts, a maximum recycling rate of $100 \%$ was assumed in the base case - the effect of different recycling rates was later studied as part of the sensitivity analysis. The efficiency of the recycling process (output divided by its input) was also taken into account when crediting the system for the recycled materials. For glass, the recycling efficiency was taken as $100 \%$ whereas for steel and aluminium, a value of $85 \%$ was assumed (World Steel Association, 2011). Only the major components of the system were considered in the recycling or disposal analysis and minor components, such as iron or bronze, were neglected due to a lack of data.

Table 4. End-of-life data for the SWH system

\begin{tabular}{|c|c|c|c|}
\hline Material & Landfilling $^{\mathbf{a}}$ & Recycling $^{\mathbf{a}}$ & Amount $^{\mathrm{b}}(\mathrm{kg})$ \\
\hline Steel & Disposal of inert material to landfill & Treatment of waste steel, recycling & $90.78[109.01]$ \\
\hline Aluminium & Disposal of aluminium to sanitary landfill & $\begin{array}{l}\text { Treatment of aluminium scrap, post- } \\
\text { consumer, prepared for recycling, at } \\
\text { smelter }\end{array}$ & 1.8 \\
\hline Copper & Disposal of copper, municipal incineration & $\begin{array}{l}\text { Disposal of copper, municipal } \\
\text { incineration }\end{array}$ & 2.82 \\
\hline Tempered glass & Disposal of inert material to landfill & Glass recycling, including credits ${ }^{c}$ & 22.5 \\
\hline $\begin{array}{l}\text { Polyurethane } \\
\text { foam }\end{array}$ & Disposal of polyurethane foam to landfill & $\begin{array}{l}\text { Disposal of polyurethane foam to } \\
\text { landfill }\end{array}$ & $5.28[10.52]$ \\
\hline
\end{tabular}

\subsubsection{Estimation of energy output from the SWH system}

The energy requirement for the daily domestic hot water supply to the household was calculated as follows:

$Q_{H W}=\dot{V}_{H W} \times C_{p, w} \times \rho_{w} \times\left(T_{h, o}-T_{c, i}\right)$

where:

$Q_{H W} \quad$ daily energy requirement for the household domestic hot water supply (W)

$\dot{V}_{H W} \quad$ daily requirement of domestic hot water (100 1/day)

$C_{p, w}$ average specific heat of liquid water $\left(4.18 \mathrm{~kJ} / \mathrm{kg} .{ }^{\circ} \mathrm{C}\right)$

$\rho_{w} \quad$ average density of liquid water $\left(1000 \mathrm{~kg} / \mathrm{m}^{3}\right)$

$T_{h, o} \quad$ temperature of hot water at the outlet of the collector $\left({ }^{\circ} \mathrm{C}\right)$

$T_{c, i}$ temperature of cold water at the inlet into the collector $\left({ }^{\circ} \mathrm{C}\right)$. 
While $T_{h, o}$ was kept constant at $60^{\circ} \mathrm{C}$ in all calculations, $T_{c, i}$ depends on the location and the time of the year and is therefore a variable. These values are provided in Table 5, together with the solar irradiation in the selected locations in Regions 1-4. Both the water inlet temperature and solar irradiation datasets were obtained from the literature (Abuska, 2012). The typical overall efficiency of flat-plate collector SWH systems, defined as the percentage of the heat transferred to water relative to the incoming solar energy, was assumed at 70\% (Chen, et al., 2012; Viridian Solar, 2016). The way the efficiency is defined in this study means that it is independent of where or at what conditions the SWH unit is used. Therefore, all the SWH in all the regions would have the same efficiency. However, this does not mean that the energy output of the SWH system would be the same everywhere because different regions would have different insolation values. Although the heat losses from the SWH would change from location to location due to the variation in the ambient temperature and, consequently, the efficiency may vary, this effect was neglected assuming that the system was well-insulated. It was also assumed that the daily requirement for hot water did not change in different regions. This assumption is valid as the focus is on the supply of domestic hot water and not on hot water for space heating, which would vary with location.

After calculating the energy requirement using Eq. (1) for each month in each location, the energy provided by the $2.25 \mathrm{~m}^{2} \mathrm{SWH}$ system was calculated based on the average monthly solar irradiation value in each location and the typical overall efficiency of the SWH system, as follows:

$$
Q_{\text {out }}=2.25 \times 0.7 \times A S I \quad \quad(\mathrm{kWh} / \text { day })
$$

where:

$Q_{\text {out }} \quad$ energy provided by the SWH system on a daily basis (kWh/day)

2.25 effective surface area $\left(\mathrm{m}^{2}\right)$

0.7 efficiency of the solar collector (-)

ASI average solar irradiation for a given region (Table 5) $\left(\mathrm{kWh} / \mathrm{m}^{2}\right.$.day).

If the energy $Q_{\text {out }}$ provided by the $\mathrm{SWH}$, estimated by Eq. (2), was greater than the daily hot water demand by the household $Q_{H W}$ (Eq. (1)), then $Q_{o u t}$ was assumed to be equal to $Q_{H W}$ and the surplus heat was not considered. If, on the other hand, the SWH system generated less $Q_{\text {out }}$ than the household's requirement $Q_{H W}$, this value was considered as the actual value supplied and no other energy supply was considered to make up the shortfall. By using this approach, the daily usable energy output from the SWH system was calculated for each of the four locations and then multiplied by the number of days in each month to obtain monthly values, which were summed up to provide the annual output of the hot water. Finally, these figures were used to determine the total amount of hot water supply over the 25-year lifespan of the SWH.

The monthly values were also used to estimate the percentage of hot water that can be obtained from the SWH system relative to the annual hot water demand of the household; this is known as the 'solar fraction'. The solar fraction was estimated for each region for each month and then their average was used to determine the overall solar fraction. Note that using the annual values for these estimates would be misleading, as there will be a lot of excess heat energy generated in the summer months which cannot be used to compensate for the inadequate heat energy in the winter months. On the other hand, using daily values would be more accurate than using monthly values. However, such an analysis would require daily solar irradiation data for all the regions, which were not available. 
In addition to the energy output, energy inputs in the life cycle of the system were also calculated together with the related output-to-input ratios. The results of this analysis are presented in section 3.1 .

\subsubsection{Natural gas boiler}

Natural gas boiler is the most common water heating source in Turkey and was considered here as an alternative to the SWH system. It should also be noted that even in regions where solar radiation is abundant, SWH systems must be backed up by a gas boiler to ensure a continuous and sufficient supply. However, as explained in the previous section, the boiler backup was not considered, in accordance with the goal and scope of the study. A modulating condensing natural gas boiler was assumed as an alternative (or a backup) to the $\mathrm{SWH}$, with the installed capacity of $<100 \mathrm{~kW}$, an efficiency of 85\% (CleaverBrooks, 2010) and a lifetime of 25 years (Beccali, et al., 2016). Like the SWH system, its life cycle boundary was also from 'cradle to grave', encompassing extraction and production of natural gas and raw materials for the boiler, its manufacture, operation, maintenance and end-of-life waste management. Boilers were assumed to be manufactured in Istanbul and then transported by lorries $(<16 \mathrm{t})$ to the point of use, taking into account the actual distances between Istanbul and the cities in the other three regions (700 km to Antalya, $450 \mathrm{~km}$ to Ankara, and 1240 $\mathrm{km}$ to Erzurum). Transport of the manufacturing materials was also considered (650 $\mathrm{km}$ for aluminium and $590 \mathrm{~km}$ for copper and steel). The boiler was assumed to be landfilled at the end of its useful life.

The LCA data for the boiler were sourced from Ecoinvent v2.2 (Ecoinvent, 2017), adapted for the Turkish energy mix and assuming that the boiler generates the same amount of heat as the SWH in the four climatic regions (see Table 7). Inventory data for the materials and energy used in the boiler manufacture were obtained from the literature (Vignali, 2017).

Table 5. Average monthly water temperatures at the inlet of the collector $\left(T_{c}, i\right)$ and solar irradiation for the studied locations

\begin{tabular}{|c|c|c|c|c|c|c|c|c|}
\hline \multirow[t]{2}{*}{ Month } & \multicolumn{2}{|c|}{ Antalya (Region 1) } & \multicolumn{2}{|c|}{ Istanbul (Region 2) } & \multicolumn{2}{|c|}{ Ankara (Region 3) } & \multicolumn{2}{|c|}{ Erzurum (Region 4) } \\
\hline & $\begin{array}{l}\text { Water } \\
\text { inlet temp. } \\
\left({ }^{\circ} \mathrm{C}\right)\end{array}$ & $\begin{array}{l}\text { Average solar } \\
\text { irradiation } \\
\left(\mathrm{kWh} / \mathrm{m}^{2} \cdot \text { day }\right)\end{array}$ & $\begin{array}{l}\text { Water inlet } \\
\text { temp. } \\
\left({ }^{\circ} \mathrm{C}\right)\end{array}$ & $\begin{array}{l}\text { Average solar } \\
\text { irradiation } \\
\left(\mathrm{kWh} / \mathrm{m}^{2} \cdot \text { day }\right)\end{array}$ & $\begin{array}{c}\text { Water } \\
\text { inlet temp. } \\
\left({ }^{\circ} \mathrm{C}\right)\end{array}$ & $\begin{array}{l}\text { Average solar } \\
\text { irradiation } \\
\left(\mathrm{kWh} / \mathrm{m}^{2} \cdot \text { day }\right)\end{array}$ & $\begin{array}{c}\text { Water } \\
\text { inlet temp. } \\
\left({ }^{\circ} \mathrm{C}\right)\end{array}$ & $\begin{array}{l}\text { Average solar } \\
\text { irradiation } \\
\left(\mathrm{kWh} / \mathrm{m}^{2} \text { day }\right)\end{array}$ \\
\hline January & 13.8 & 2.2 & 10.2 & 1.3 & 8.2 & 1.5 & 2.7 & 1.7 \\
\hline February & 12.7 & 3.0 & 9.0 & 2.1 & 6.6 & 2.3 & 1.5 & 2.6 \\
\hline March & 13.9 & 4.1 & 9.5 & 3.1 & 7.8 & 3.5 & 1.1 & 3.6 \\
\hline April & 16.1 & 5.2 & 11.8 & 4.6 & 10.7 & 4.8 & 3.2 & 4.9 \\
\hline May & 19.5 & 6.1 & 15.4 & 5.7 & 14.5 & 6.1 & 7.5 & 5.9 \\
\hline June & 23.5 & 6.6 & 19.2 & 6.3 & 18.0 & 6.8 & 11.8 & 6.7 \\
\hline July & 26.8 & 6.4 & 21.9 & 6.0 & 20.9 & 7.1 & 14.8 & 6.8 \\
\hline August & 28.5 & 5.8 & 22.9 & 5.4 & 22.8 & 6.3 & 16.8 & 6.2 \\
\hline September & 27.8 & 4.9 & 22.4 & 4.1 & 21.6 & 5.0 & 16.1 & 4.9 \\
\hline October & 25.2 & 3.6 & 19.8 & 2.8 & 18.1 & 3.4 & 12.5 & 3.4 \\
\hline November & 21.5 & 2.6 & 16.9 & 1.7 & 14.6 & 2.1 & 8.5 & 2.1 \\
\hline December & 17.0 & 2.0 & 13.2 & 1.9 & 10.9 & 1.2 & 5.3 & 1.5 \\
\hline
\end{tabular}

\subsubsection{Country-wide implications of using SWH systems}

This part of work aimed to estimate the environmental impacts of using the SWH systems at the national level. For these estimates, the number of households in Turkey with the SWH system was determined using the city population data (Turkish Institute of Statistics, 2016) in seven geographical regions and the percentage ownership of SWH (Table 6). Each geographical region 
was assigned to a particular climatic region (1 to 4 ) according to the prevalent type of climate. It was assumed that each city in a particular climatic region represented the SWH output data for that entire region. In total, 81 cities in the seven geographical regions were included in the analysis. However, given the collector and tank size, the SWH systems considered in this work are applicable for detached houses only. Therefore, the country-wide implications of their use were calculated for detached houses only, which provide accommodation for approximately $40 \%$ of the Turkish population (Anon., 2009). The same size of the household was assumed as before (four people). Hence, the number of detached houses with a SWH system in each city was calculated as follows:

$D H_{S W H}=O R \times(P \times 0.4) / 4$

where:

$\mathrm{DH}_{S W H} \quad$ number of detached houses with a SWH system (-)

OR ownership rate for each region (Table 6) (-)

$P \quad$ population in each city (-)

$0.4 \quad$ ratio of population with detached houses (-)

4 number of people per household.

The $\mathrm{DH}_{\mathrm{SWH}}$ values estimated for each city were added up to estimate the actual number of SWH systems in Turkey.

Table 6. Ownership of SWH systems in different geographical regions in Turkey (Altuntop \& Erdemir, 2013)

\begin{tabular}{lc}
\hline Geographical region & Ownership (\%) \\
\hline Mediterranean (south coast) & 70 \\
Aegean (west coast and mid-west) & 45 \\
South-eastern Anatolia (southeast) & 40 \\
Central Anatolia (middle) & 25 \\
Eastern Anatolia (mid-east and eastern) & 15 \\
Marmara (northwest) & 5 \\
Karadeniz (north coast) & 5 \\
\hline
\end{tabular}

\section{Results and discussion}

This section first presents the results for the energy output from the SWH systems, followed by a discussion of the environmental impacts considered in the study.

\subsection{Energy output from the SWH system}

The results in Table 7 and Figure 3 suggest that Antalya (Region 1) is the best region for the utilisation of SWH, with the solar fraction of 92\%, meaning that almost all household needs for hot water can be met by the system. This shortfall in self-sufficiency is due to the (small) size of the system rather than due to the climatic region. Although the energy output over the lifetime of the system in Region 1 (37.95 MWh) is lower than in Regions 3 and 4 (Figure 3), its low life cycle energy inputs result in an overall high energy output-to-input ratio (26.6 vs. 7.2 and 7.9 in Regions 3 and 4 , respectively). The low energy output in Region 1 can be misleading, as the geography suggests that a southern city like Antalya should receive much more solar radiation than cities in Regions 3 or 4 . Actually, that is precisely the case; however, the energy requirement for water heating in Antalya is also low (as per eqn. (1), high water inlet temperature means lower energy 
requirement). Therefore, the energy used for water heating in Antalya is lower than in the other cities and regions. The high energy output-to-input ratio in Antalya can also be attributed to the lack of a pump: continuous water circulation is not necessary in this region since even winter temperatures almost never reach the freezing point.

However, the other three climatic regions are not far behind, with around $80 \%$ of the households' hot water needs supplied by the SWH systems (Table 7). It can be noticed that there is little difference between the three regions in terms of the energy output, despite quite a different climate. This is mainly due to the geography. In other words, even in regions like Istanbul or Erzurum, where the solar irradiation is relatively low, energy input to the system is more than enough to provide the energy output for domestic hot water supply. Another possible reason may be the relatively low domestic hot water consumption in Turkey compared to developed countries such as the US, where a typical household with three people consumes twice as much (193 litres) hot water (Florida Solar Energy Center, 2015).

It can also be noticed from Figure 3 that, in all four regions, the energy output of the SWH system over its lifetime surpassed significantly the energy required for its manufacturing, operation, and end-of-life treatment. In Regions 1 and 2, the average energy output-input ratio is 26.6, whereas in Regions 3 and 4 the ratio decreases to 7.6 due to the energy consumption by the heat exchanger unit. Based on these results, the average energy payback period in Regions 1 and 2 is approximately 1 year and in regions 3 and 4 , around 3.3 years.

Recycling does not affect significantly the energy balance of the SWH over the lifetime (Figure 3), with the greater difference in favour of recycling (7\%-8\%) found for Regions 1 and 2 than for the other two (2\%). This is due to the lower energy output in Regions 1 and 2 and a relatively greater influence of the recycling credits.

Table 7. Estimated energy output from the SWH system

\begin{tabular}{|c|c|c|c|c|}
\hline Time period & $\begin{array}{c}\text { Antalya } \\
\text { (Region 1) } \\
(\mathbf{k W h})\end{array}$ & $\begin{array}{c}\text { Istanbul } \\
\text { (Region 2) } \\
(\mathbf{k W h})\end{array}$ & $\begin{array}{c}\text { Ankara } \\
\text { (Region 3) } \\
(\mathbf{k W h})\end{array}$ & $\begin{array}{c}\text { Erzurum } \\
\text { (Region 4) } \\
(\mathbf{k W h}) \\
\end{array}$ \\
\hline January & 105.8 & 62.4 & 71.8 & 81.4 \\
\hline February & 131.0 & 91.8 & 102.8 & 113.9 \\
\hline March & 166.1 & 149.2 & 172.2 & 177.6 \\
\hline April & 153.0 & 168.0 & 171.9 & 198.0 \\
\hline May & 145.9 & 160.7 & 163.9 & 183.0 \\
\hline June & 127.2 & 142.2 & 146.4 & 168.0 \\
\hline July & 119.6 & 137.2 & 140.9 & 162.8 \\
\hline August) & 113.5 & 133.6 & 134.0 & 155.6 \\
\hline September & 112.3 & 131.1 & 133.9 & 153.0 \\
\hline October & 125.4 & 137.0 & 150.9 & 165.4 \\
\hline November & 122.1 & 81.4 & 99.7 & 97.1 \\
\hline December & 96.3 & 95.1 & 59.6 & 74.5 \\
\hline Total annual output & 1518.0 & 1489.7 & 1548.0 & 1730.6 \\
\hline Total over 25 years & 37,950 & 37,242 & 38,700 & 43,265 \\
\hline Solar fraction (\%) & 91.8 & 81.4 & 82.2 & 81.0 \\
\hline
\end{tabular}




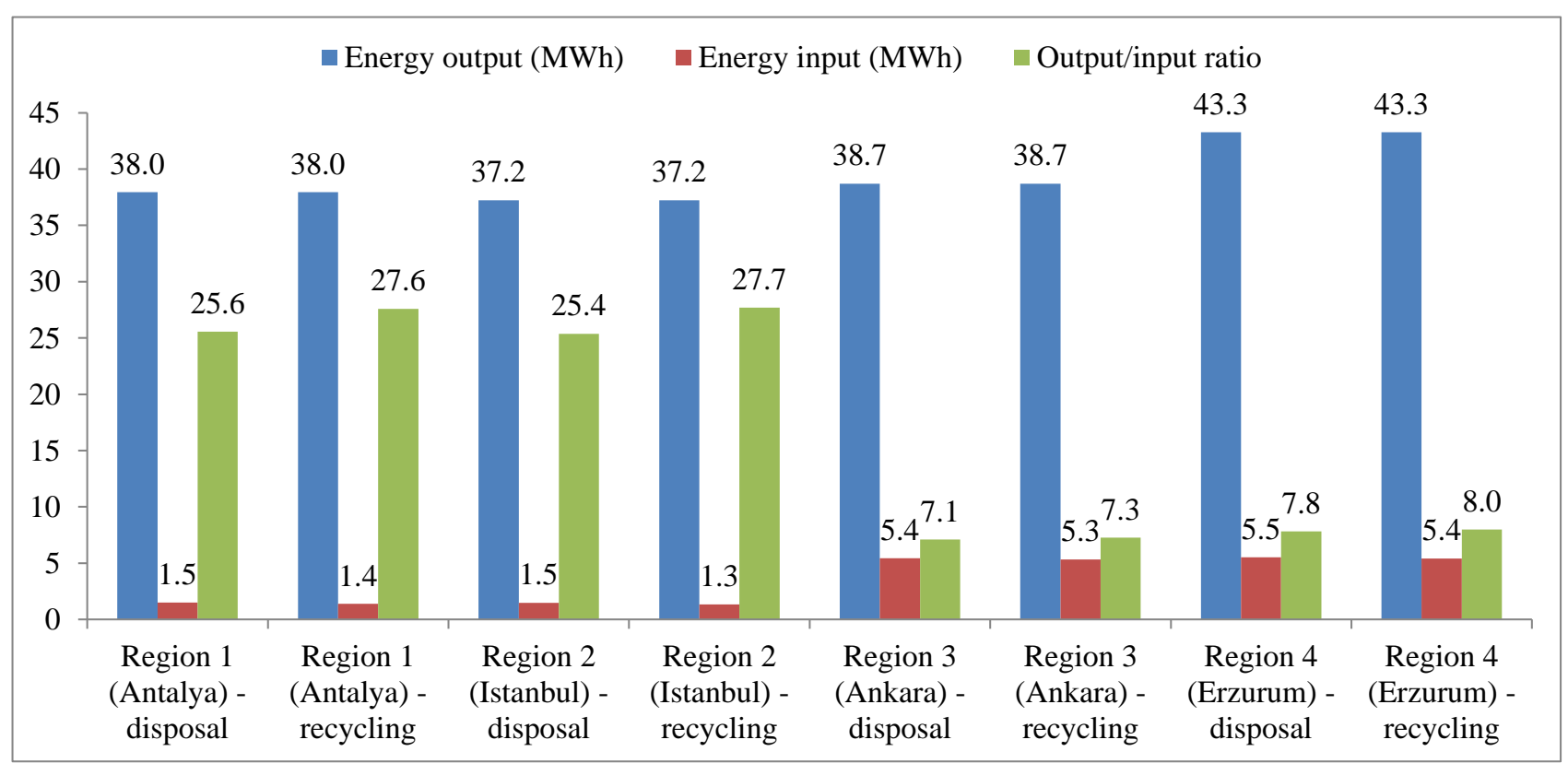

Figure 3. Energy input and output for the SWH systems over the lifetime in different climatic regions and for different end-of-life scenarios

\subsection{Global warming potential (GWP)}

As shown in Figure 4, utilisation of the SWH in Regions 1 and 2 leads to around 3.5 times lower GWP than in Regions 3 and 4, respectively. This is due to the electricity consumption by the heatexchanger pump, which in the latter regions accounts for more than $50 \%$ of the total, with the rest being attributed to the raw materials used for manufacturing the SWH system. However, their respective contributions in Regions 1 and 2 are quite different, with the raw materials accounting for around $75 \%$ of the overall impact.

Recycling the raw materials does not make a significant difference to the GWP, reducing it by $10 \%$ in Regions 1 and 2 and by $3.5 \%$ in Regions 3 and 4. This can be attributed to a high energy intensity of steel and glass recycling, as these two materials constitute more than $94 \%$ of the overall recycled content. It has been reported in the literature that using recycled glass instead of virgin glass can in certain cases provide an energy recovery of only 5\% (Achintha, 2016), whereas for steel this value is around 25\% (World Steel Association, 2011). As far as aluminium is concerned, an energy recovery of $95 \%$ is possible, but aluminium has a very small share in the overall system so that its recycling does not affect this impact. The contribution of transport to the GWP is negligible.

Figure 4 also reveals that, in comparison to the gas boiler, the SWH system has a much lower GWP, as could be expected. The difference between these two options is much higher in Regions 1 and 2 ( 27 times in favour of SWH) than in the other two regions (8.5 times). Thus, the SWH system provides significant savings of greenhouse gas emissions relative to the gas boiler. 


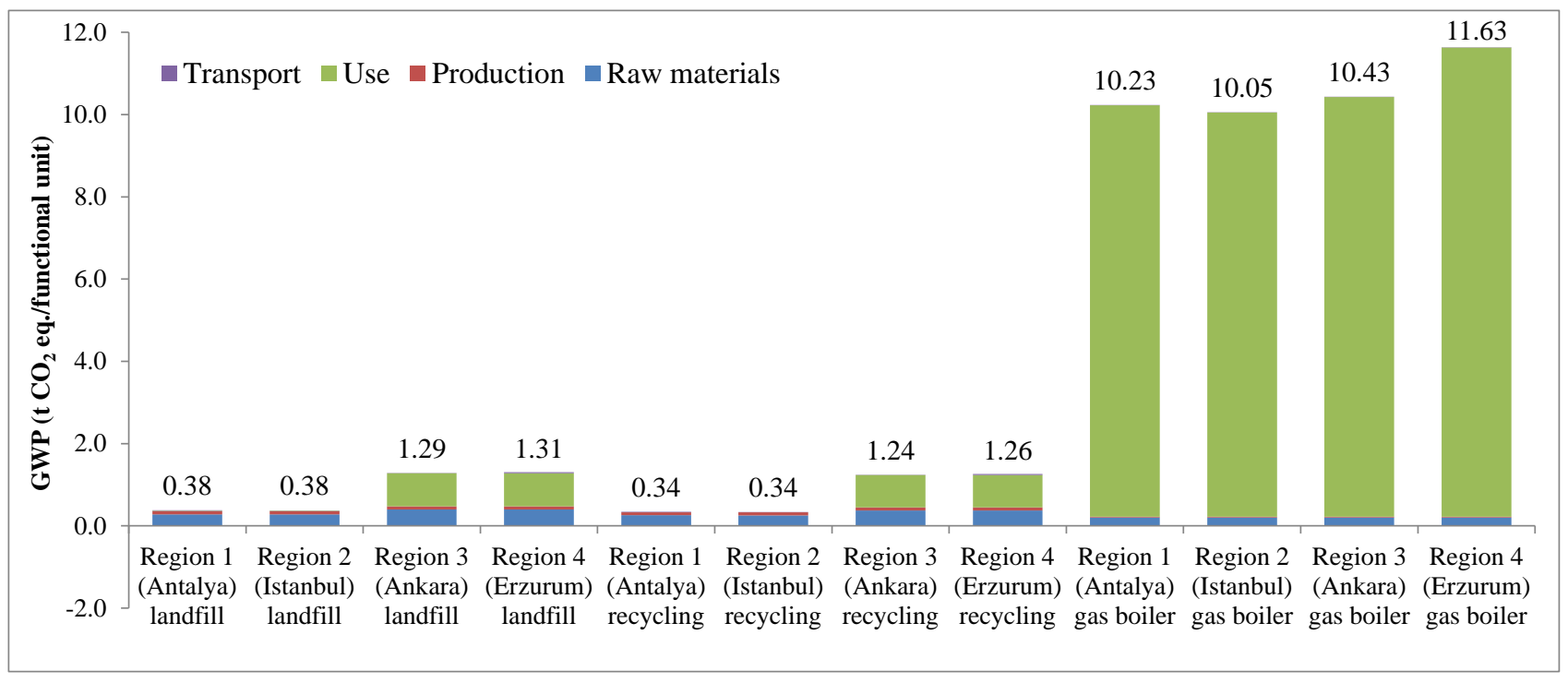

Figure 4. Global warming potential (GWP) of the SWH system in the four climatic regions over the lifetime of 25 years for different end-of-life management options in comparison with the natural gas boiler, also showing the contribution of different life cycle stages

\subsection{Acidification potential (AP)}

The results in Figure 5 suggest that using SWH systems in Regions 3 and 4 leads to a factor of $\sim 8.5$ higher AP than in Regions 1 and 2. Their impact in the former two regions is also around four times higher than the AP of the gas boiler. This is due to the electricity used by the heat-exchanger pump. Turkish electricity has a relatively high AP (Atilgan \& Azapagic, 2016) for two reasons. First, Turkish lignite, which provides $17 \%$ of the country's electricity, has a high sulphur content of $3 \%$ (Canel, et al., 2016). Secondly, installing desulphurisation units in power plants is not mandatory in Turkey and only $47 \%$ of the coal power plants have these systems (Cift \& Okutan, 2010). Thus, using SWH in Regions 1 and 2 is beneficial with respect to the AP compared to the gas boiler, but in the other two regions, the gas boiler is a better option.

As can also be seen in Figure 5, the use stage contributes the majority of the impact in Regions 3 and 4 while in the other two, the main contributors are the SWH manufacturing process and the raw materials. The AP is not affected by recycling and transport. 


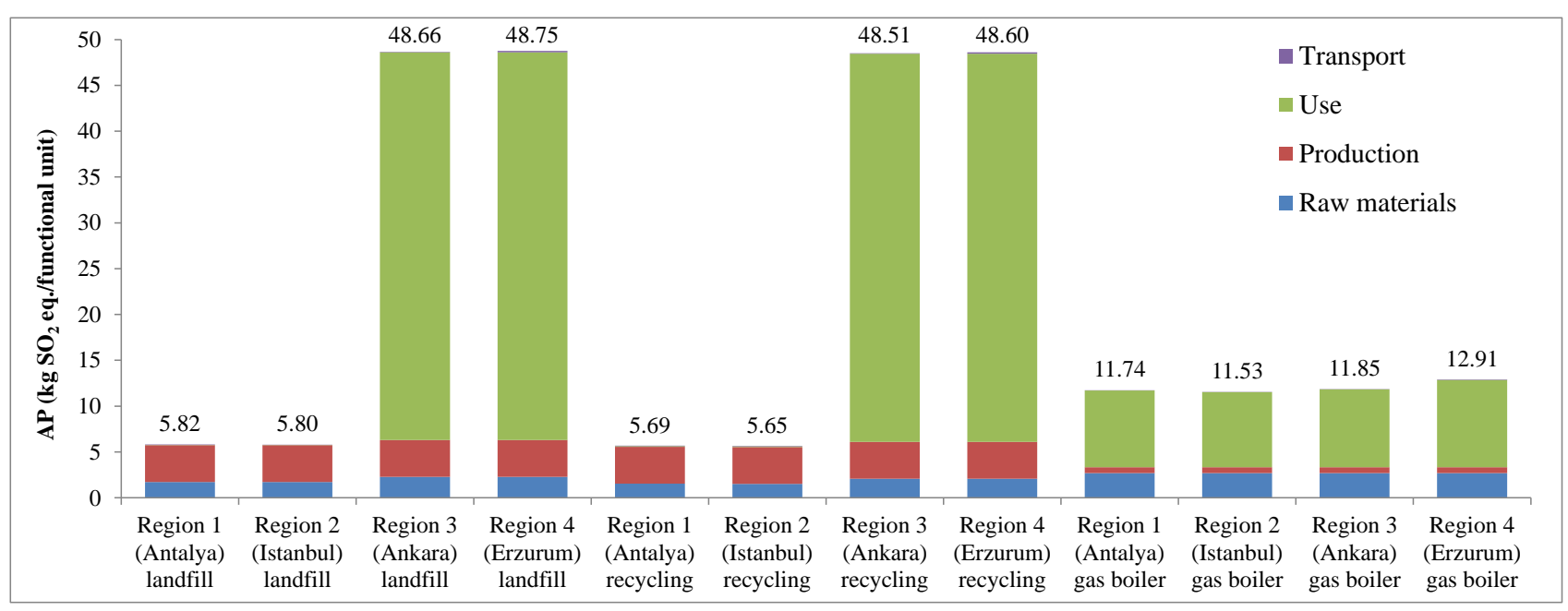

Figure 5. Acidification potential (AP) of the SWH system in the four climatic regions over the lifetime of 25 years for different end-of-life management options in comparison with the natural gas boiler, also showing the contribution of different life cycle stages

\subsection{Eutrophication potential (EP)}

Similar to the GWP and AP, the EP of the SWH systems in Regions 3 and 4 is also higher than in the other two areas (Figure 6). However, the difference in the EP between the regions is much smaller, averaging at around $35 \%$. The main reason for this is that the use stage (mainly electricity consumption for pumping) in Regions 3 and 4 has a smaller contribution to the AP (14\%). Instead, the main contributors are the raw material (82\%), particularly aluminium and copper. The contributions of manufacturing and transport are small (2.3\% and $1.5 \%$, respectively).

Compared to the gas boiler, the SWH system is a better option for the EP in all four regions, although the benefits are greater in Regions 1 and 2. There, the impact is around four times lower compared to 2.7 times lower in the other two regions. Therefore, in contrast with the AP, SWH is environmentally more sustainable than the gas boiler with respect to the EP.

\subsection{Photochemical oxidants creation potential (POCP)}

The SWH systems in Regions 1 and 2 have around three times lower POCP than in Regions 3 and 4 (Figure 7) and around eight times smaller impact than the gas boiler. The main cause of POCP is the emissions of $\mathrm{SO}_{2}, \mathrm{CO}, \mathrm{NO}_{\mathrm{x}}$ and non-methane volatile organic compounds from the production of steel and copper used to manufacture the SWH, as well as the electricity for the heat-exchanger pump and the production of propylene glycol. The effect of transportation and end-of-life management is small. 


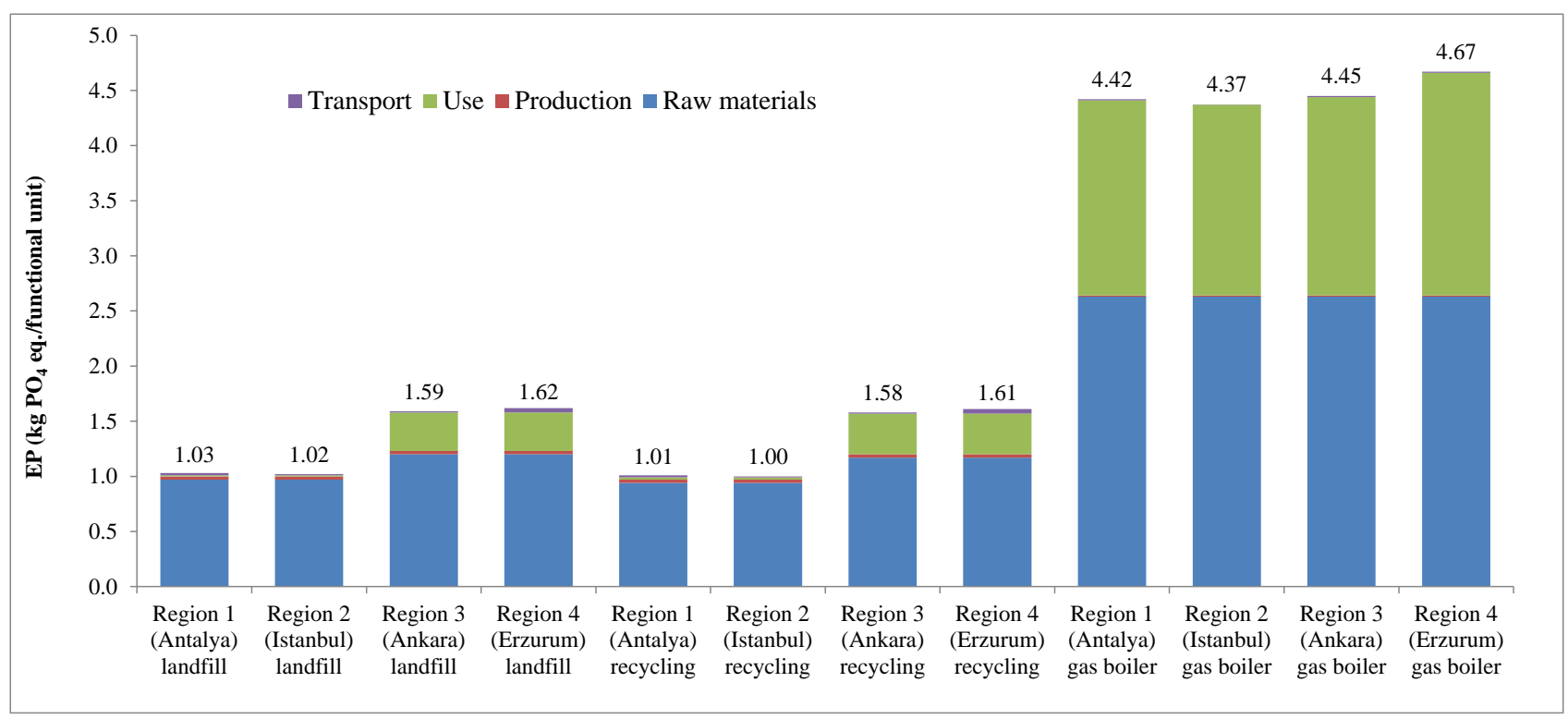

Figure 6. Eutrophication potential (EP) of the SWH system in the four climatic regions over the lifetime of 25 years for different end-of-life management options in comparison with the natural gas boiler, also showing the contribution of different life cycle stages

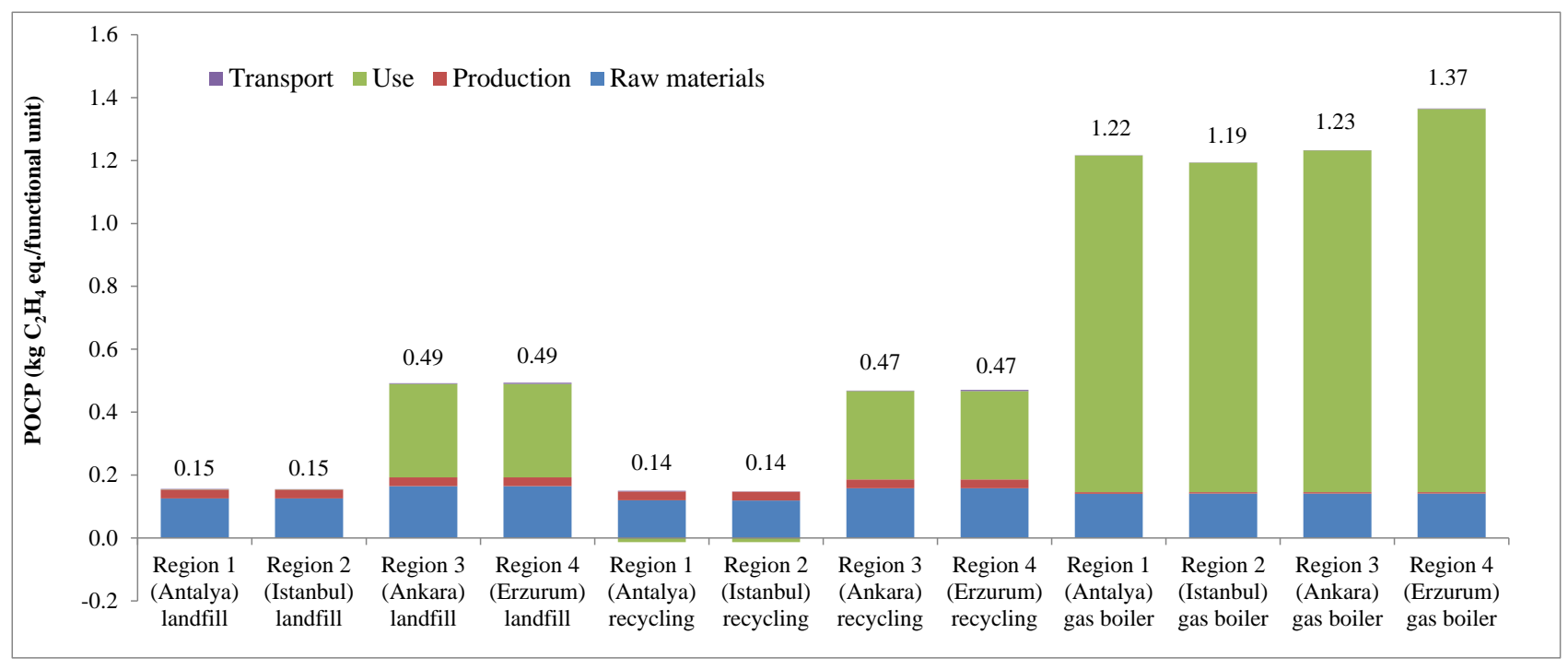

Figure 7. Photochemical oxidants creation potential (POCP) of the SWH system in the four climatic regions over the lifetime of 25 years for different end-of-life management options in comparison with the natural gas boiler, also showing the contribution of different life cycle stages

\subsection{Ozone layer depletion potential (ODP)}

As shown in Figure 8, ODP of the SWH system is around five times lower in Regions 1 and 2 than in 3 and 4, again because of the electricity used by the pump. The reason for the high ODP attributed to Turkish electricity is the high contribution of natural gas ( $45 \%)$ and the associated use of halons as fire suppressants in gas pipelines (Atilgan \& Azapagic, 2015). However, despite that, the impact from SWH in Regions 3 and 4 is still 16 times lower than from the gas boiler. For the other two 
regions, the difference is much starker: 73 times in favour of SWH. As for most other impacts, the contribution of the manufacturing, end-of-life and transport stages is insignificant.

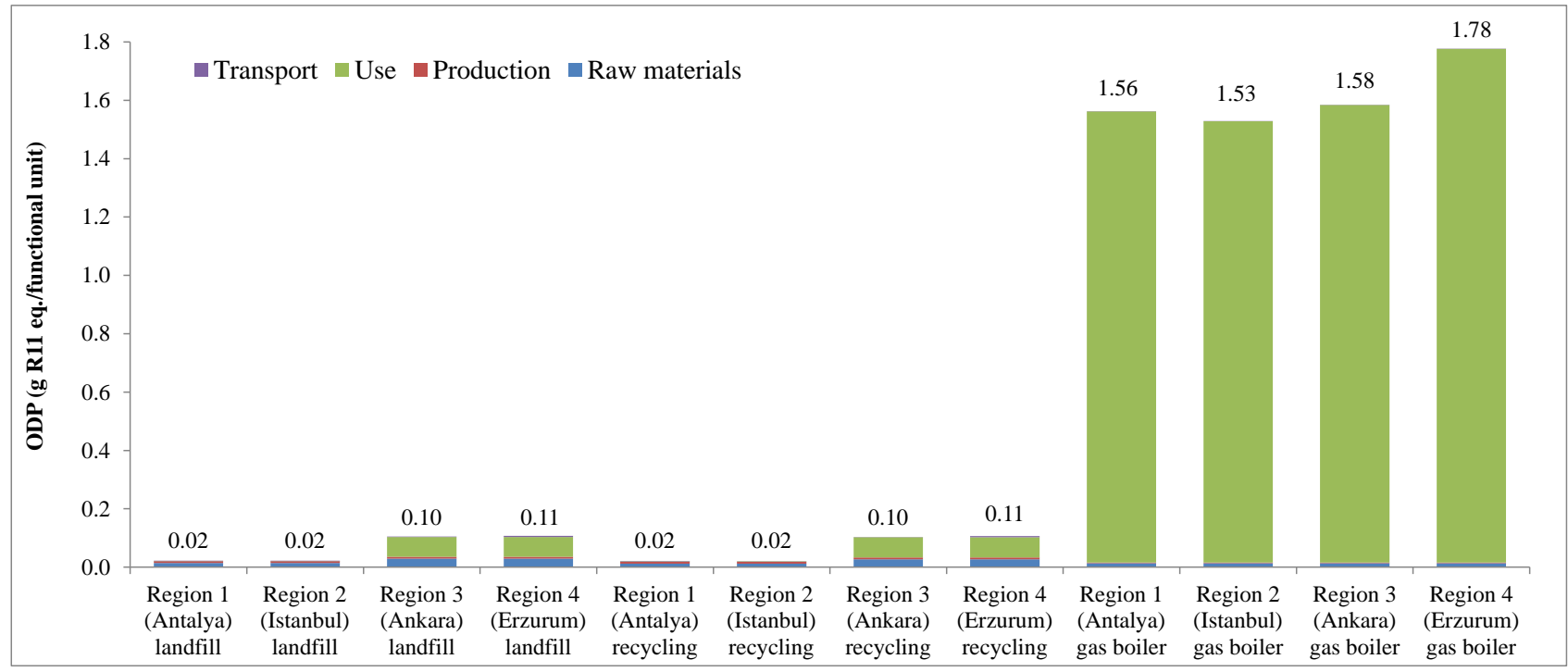

Figure 8. Ozone layer depletion (ODP) of the SWH system in the four climatic regions over the lifetime of 25 years for different end-of-life management options in comparison with the natural gas boiler, also showing the contribution of different life cycle stages

\subsection{Human toxicity potential (HTP)}

The HTP of the SWH systems is two times lower in Regions 1 and 2 than in the other two if the systems are landfilled at the end of life (Figure 9). However, it they are recycled, the difference between the respective regions increases to around five times. This is because the recycling of metals has a much higher effect on this impact, reducing it by four times in Regions 1 and 2 compared to the landfilling option, and by $70 \%$ in Regions 3 and 4 . This in turn is due to the avoided emissions of chromium and arsenic in the manufacture of virgin steel and aluminium (Greening \& Azapagic, 2014). A further reason for the higher impact in Regions 3 and 4 is the high HTP of Turkish electricity mix (Atilgan \& Azapagic, 2016).

If the SWH systems are landfilled, their HTP in Regions 1 and 2 is around three times lower compared to the gas boiler but only around 30\% in Regions 3 and 4. If, on the other hand, the SWH systems are recycled, their impact is $\sim 13$ times lower than for the gas boiler in Regions 1 and 2 and $\sim 2.5$ times better in the other two regions. Therefore, recycling is critical for reducing HTP of SWH, particularly in Regions 1 and 2. 


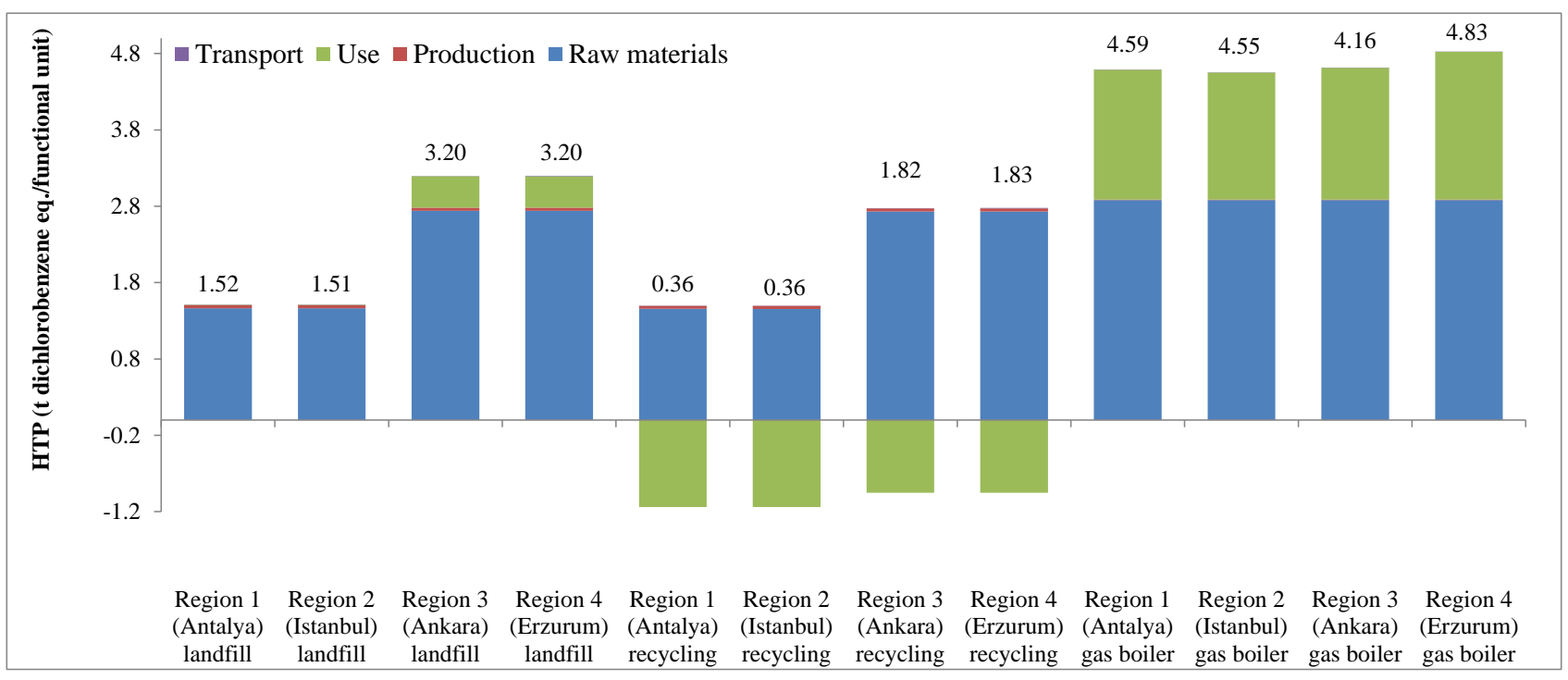

Figure 9. Human toxicity potential (HTP) of the SWH system in the four climatic regions over the lifetime of 25 years for different end-of-life management options in comparison with the natural gas boiler, also showing the contribution of different life cycle stages

\subsection{Comparison to other studies}

There is no other study of SWH systems in Turkey, so comparison with other studies was not possible. Comparison with studies in other countries discussed in the introduction section is difficult for a range of reasons, including differences in the size of the SWH system, systems boundaries, background energy mixes, impact categories considered and impact assessment methodologies used. For that reason, only a comparison of GWP was possible as most studies reported this impact and used the same methodology for its estimation. A further comparison was carried out with the UK study (Greening \& Azapagic, 2014) which also used the CML method to estimate the impacts. To make the results more comparable, the results in the other studies were scaled linearly to the size of the system considered here by taking into account the collector area and the useful lifetime of the system. However, this process introduces a certain level of error since not all the parameters depend on these variables. Nevertheless, as shown in Figure 10, the GWP estimated in this study is quite comparable to the values reported in the literature. Interestingly, the impact of the SWH in Turkey was found to be almost equal to that in the $\mathrm{UK}^{1}$. While the impact of Turkish electricity per $\mathrm{kWh}$ is slightly higher than in the UK (520 $\mathrm{g} \mathrm{CO}_{2}$ eq. (Atilgan \& Azapagic, 2016) vs $490 \mathrm{~g}$ (Greening \& Azapagic, 2014)), its consumption in Regions 3 and 4 is higher. On the other hand, the life cycle energy output of SWH in Turkey is also much higher as the solar radiation in Turkey is more abundant. Thus, these two opposing factors seem to balance each other out.

There is also a good agreement with the results of the study in Greece (Koroneos \& Nanaki, 2012), with the difference of $17 \%$ being attributed to the differences in the electricity mix, as the share of solid fuels in Greek electricity is significantly higher than in Turkey (EU Energy Commission, 2015). The only outlier is the US study which has half the impact estimated here and in the UK study. This could be due to the differences in the electricity mixes and errors caused by the scaling ${ }^{1}$ of the SWH since the energy requirement of industrial production usually has a non-linear

\footnotetext{
${ }^{1}$ The original value was $34 \mathrm{~g} \mathrm{CO}_{2} / \mathrm{kWh}$ but the area of the collector was $4 \mathrm{~m}^{2}$, so that the impact was scaled down linearly for the area of $2.25 \mathrm{~m}^{2}$ considered in this study. The lifespan of the SWH systems in both studies was the same (25 years).
} 
relationship with the amount of the output ('economies of scale'). Furthermore, the SWH system manufactured in the US appears to use considerably less materials than the SWH system considered in this study, which could also explain the difference in the results.

There is also a relatively good agreement between the other environmental impacts (Figure 11) estimated in this study and for the UK conditions (Greening \& Azapagic, 2014). The only notable difference is HTP which could be attributed to different assumptions on recycling of the SWH systems, which affect this impact significantly (see section 3.7). The differences in the respective electricity mixes also play a role.

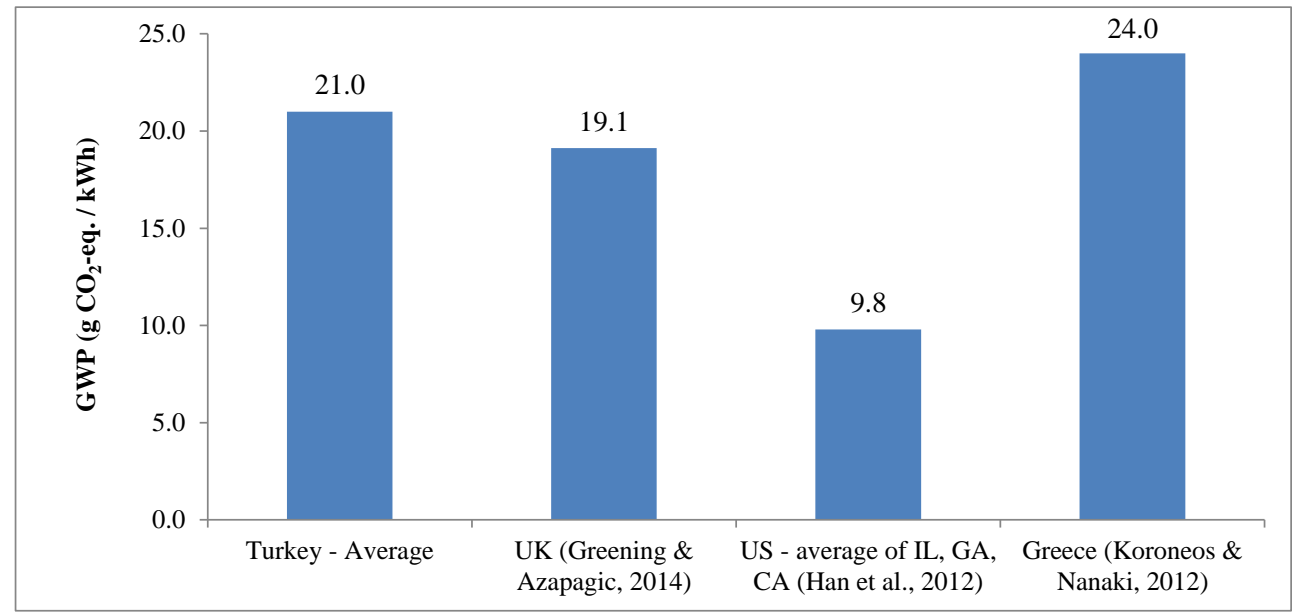

Figure 10. Comparison with the literature of the global warming potential (GWP) estimated in this study [GWP expressed per kWh of energy output from SWH.]

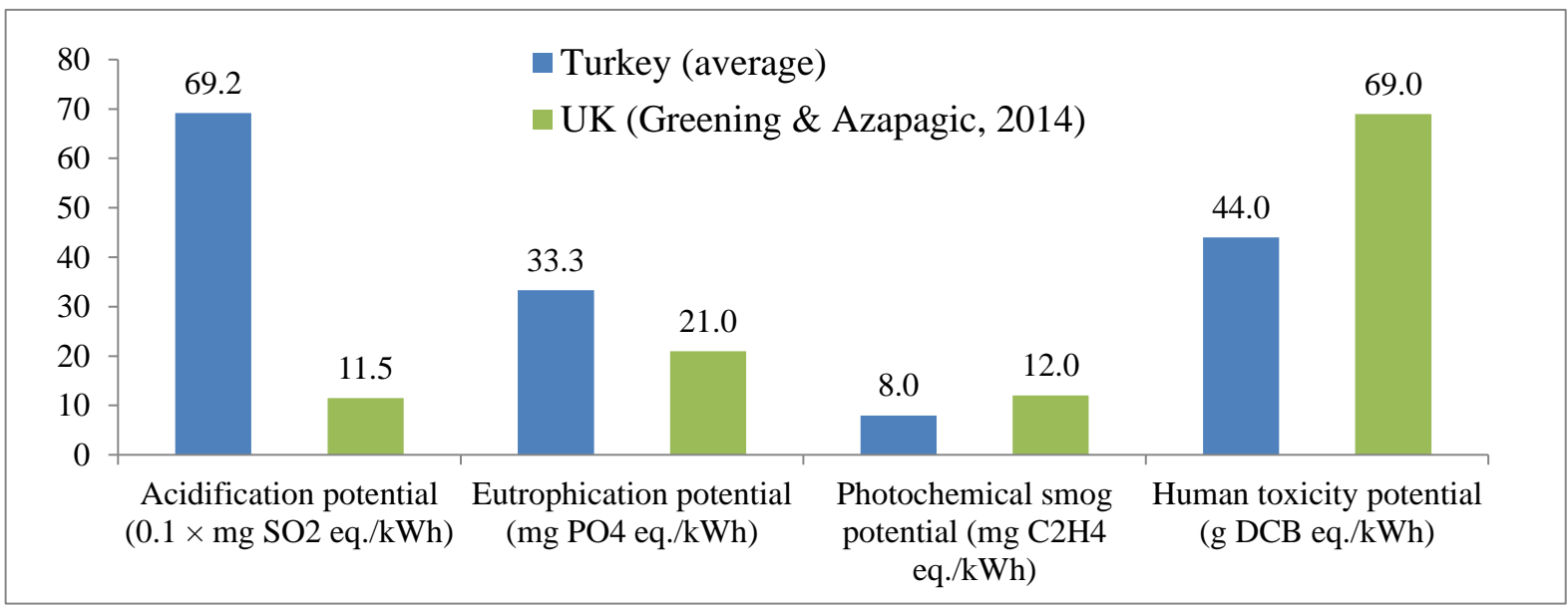

Figure 11. Comparison with the literature of other environmental impacts estimated in this study [All impacts expressed per kWh of energy output from SWH. AP: Acidification potential; EP: Eutrophication potential; POCP: Photochemical oxidants creation potential; HTP: Human toxicity potential. DCB: dichlorobenzene.] 


\subsection{Sensitivity analysis}

As discussed in sections 3.2-3.7, the main environmental hotspots in the life cycle of the SWH system are the use and raw materials stages. Therefore, their effect on the impacts is considered through a sensitivity analysis. As most of the data for the raw materials were obtained from a manufacturer, these data were regarded to be highly reliable. Therefore, instead of varying their quantities, the focus of the sensitivity analysis is on the type of material used. Specifically, copper was considered instead of steel for manufacture of the hot-water tank, as is common practice in Europe (European Commission, 2004). As copper is heavier than steel by approximately $800 \mathrm{~kg} / \mathrm{m}^{3}$ (EngineeringToolbox.com, undated), the weight of the tank would increase from 79 to $91.2 \mathrm{~kg}$. This would also affect the transport and end-of-life treatment. The energy required for the manufacturing of the tank was assumed to be the same as for the steel tank.

In the use stage, the biggest contributor to the environmental impacts is the electricity used for the heat-exchanger pump in Regions 3 and 4. Therefore, the electricity usage by the pump was varied by $\pm 10 \%$ and $\pm 20 \%$, respectively. Finally, the effect of the recycling rate was investigated by reducing it from $100 \%$ in the base case to $50 \%$ by $10 \%$ increments for all the recycled content.

As can be seen in Figure 12, the environmental impacts are highly sensitive to the tank material, with almost all the impacts for all scenarios being higher when copper is used instead of steel. HTP and EP are affected the most. The former increases by a factor of five and 8.5 for Regions 3 and 4, if the system is landfilled or recycled, respectively, and by 9.4 and 39 times in Regions 1 and 2 if the system is landfilled or recycled. The corresponding changes in the EP are between 10 and 16 times. The effect on the ODP and AP is small. Therefore, these results suggest that using steel for the hot water storage tank is environmentally more sustainable than using copper.

Varying the amount of electricity used by the pump has a less significant effect than the tank material (Figure 13). The biggest change was observed for AP, ranging between $+18 \%$ and $-17 \%$, followed by GWP, with $+12 \%$ and $-12 \%$. HTP was affected the least, fluctuating between $+2.5 \%$ and $-2.5 \%$. However, even when the electricity consumption of the pump was decreased by $20 \%$, the AP of the SWH systems in Regions 3 and 4 remained much higher (around four times) than those of natural gas boilers.

Figure 14 shows that the impacts are not sensitive to the recycling rates. The only exception is HTP which increases 2.5 times in Regions 1 and 2 and by almost 30\% in Regions 3 and 4 when the recycling rate is lowered to $50 \%$. 


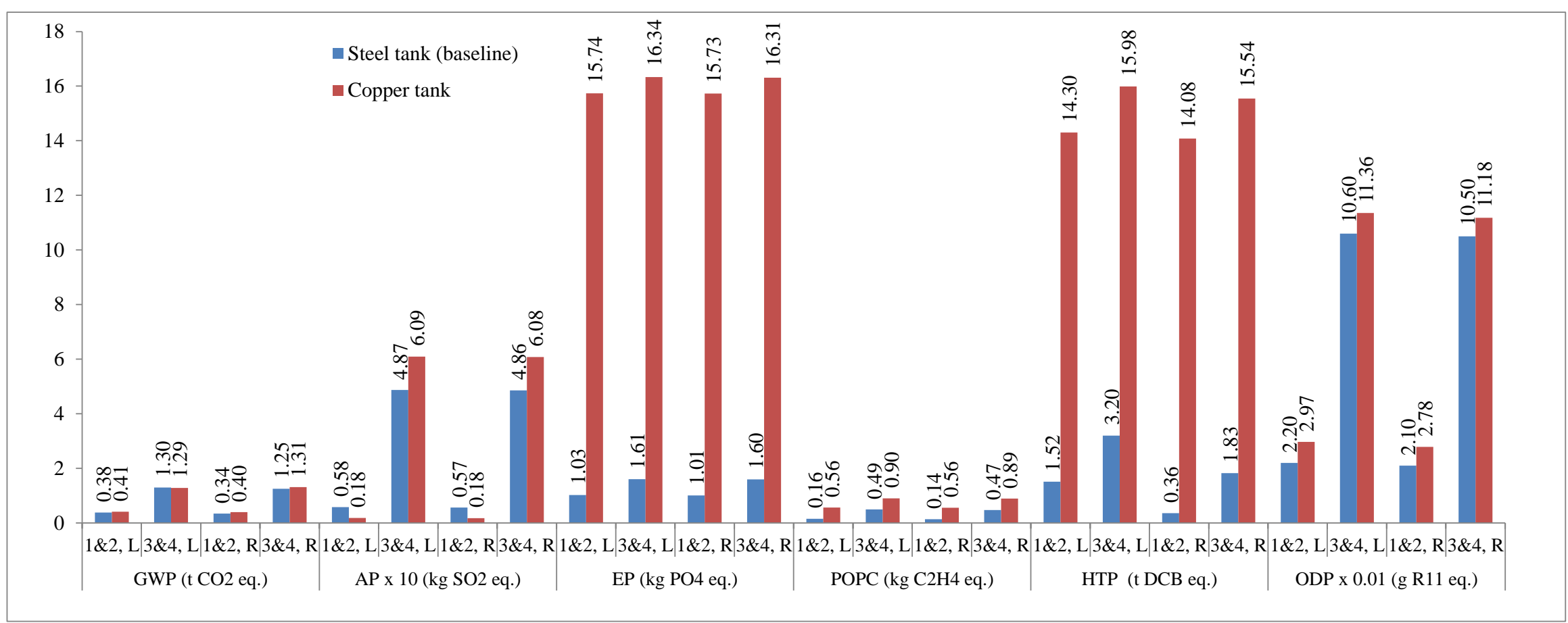

Figure 12. Sensitivity analysis for the hot-water storage tank: steel vs copper

[All impacts expressed per functional unit over the lifetime of 25 years. Some impacts have been scaled to fit. To obtain the original values, multiply with the factor shown against relevant impacts. 1\&2: Regions 1 and 2; 3\&4: Regions 3 and 4. L: landfilling; R: recycling. GWP: Global warming potential; AP: Acidification potential; EP: Eutrophication potential; POCP: Photochemical oxidants creation potential; HTP: Human toxicity potential; ODP: ozone layer depletion; DCB: dichlorobenzene.] 


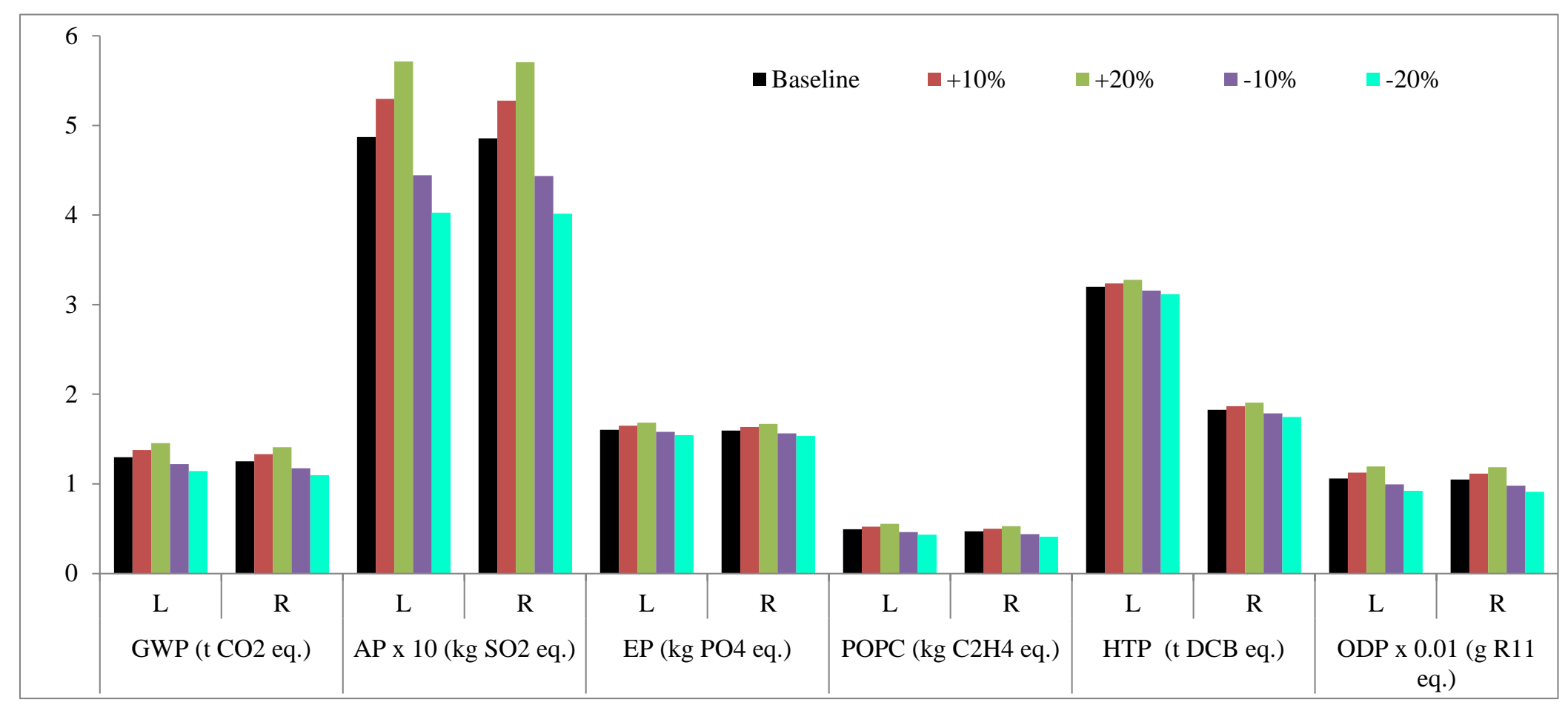

Figure 13. Sensitivity analysis assuming different consumption of electricity by the heat-exchanger pump in Regions 3 and 4 [All impacts expressed per functional unit over the lifetime of 25 years. Some impacts have been scaled to fit. To obtain the original values, multiply with the factor shown against relevant impacts. 1\&2: Regions 1 and 2; 3\&4: Regions 3 and 4. L: landfilling; R: recycling. For the impacts nomenclature, see Figure 12.] 


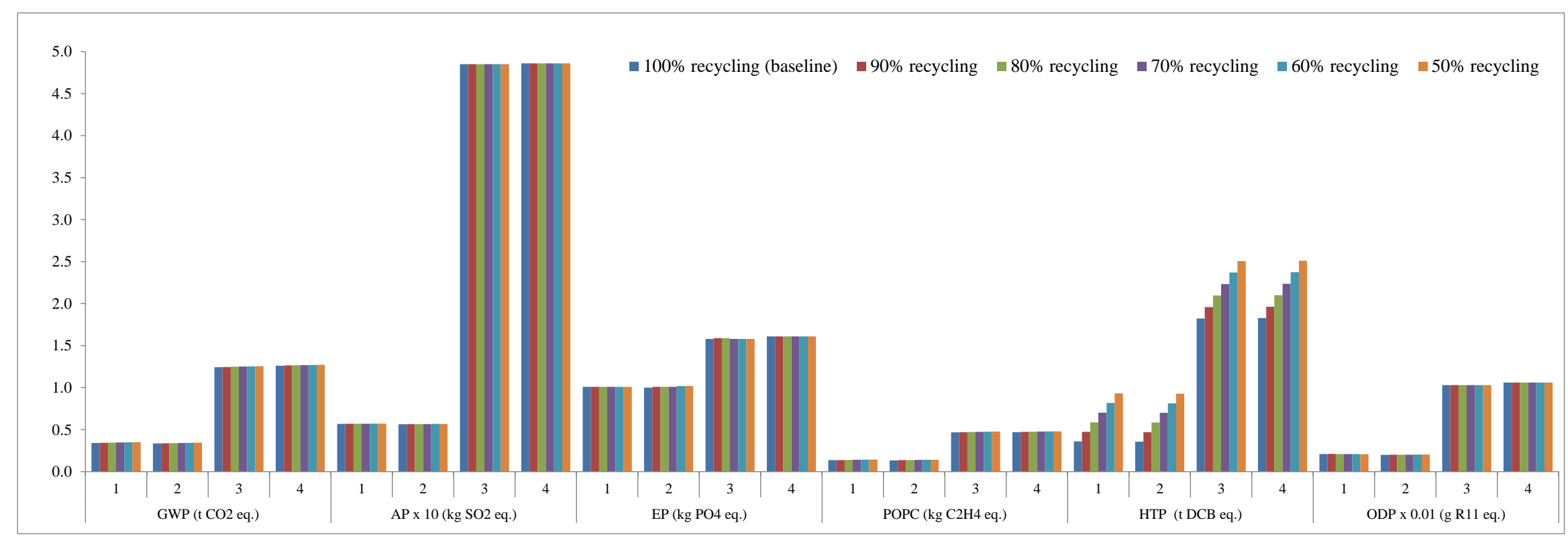

Figure 14. Sensitivity analysis assuming different end-of-life recycling rates

[All impacts expressed per functional unit over the lifetime of 25 years. Some impacts have been scaled to fit. To obtain the original values, multiply with the factor shown against relevant impacts. 1, 2, 3, 4: Regions 1, 23 and 4. For the impacts nomenclature, see Figure 12.] 


\subsection{Country-wide implications of using SWH systems}

This section considers the environmental implications of utilising the SWH systems across the whole of Turkey. The impacts were estimated based on total annual energy output from the SWH systems in detached houses of $3.196 \mathrm{TWh}$ (see section 2.2.4 for the methodology). This is equivalent to the consumption of $295,000 \mathrm{t}$ or 387 million $\mathrm{m}^{3}$ of natural gas (at standard conditions) in a typical boiler with the efficiency of $85 \%$ (EngineeringToolbox, undated).

These impacts are presented in Figure 15. As can be seen, the annual national GWP of SWH systems would be approximately $54 \mathrm{kt} \mathrm{CO}_{2}$ eq. whereas the avoided impact from the unconsumed natural gas per year would be $844 \mathrm{kt} \mathrm{CO}_{2}$ eq. Therefore, the use of SWH systems in Turkey would save approximately $844-54=790 \mathrm{kt} \mathrm{CO}$ eq. per year. To put this in context, the annual carbon emissions in Turkey in 2014 were $459.1 \mathrm{Mt} \mathrm{CO}_{2}$ eq. (Turkish Institute of Statistics, 2015); thus the SWH systems would reduce the greenhouse gas emissions by $0.17 \%$. While this appears insignificant from the climate mitigation point of view, there are other benefits of using SWH systems, including improved energy security, lower energy bills for the consumer and reduced costs of imported natural gas to the national economy. As indicated in the introduction, Turkey relies heavily on imports of natural gas and the cost of importing the above amount of natural gas at a rate of $\$ 0.42 / \mathrm{m}^{3}$ (Altuntop \& Erdemir, 2013) would be approximately $\$ 162.5$ million. Considering that the entire SWH system can be manufactured locally, in addition to contributing to the GDP, the SWH systems would contribute to the Turkish economy by saving $\$ 162.5$ million on an annual basis. These savings would be even higher for larger SWH systems and households than assumed in this study. It should also be borne in mind that only detached houses were considered here - if all other suitable buildings were to have a SWH, the GWP and economic benefits could increase several-fold.

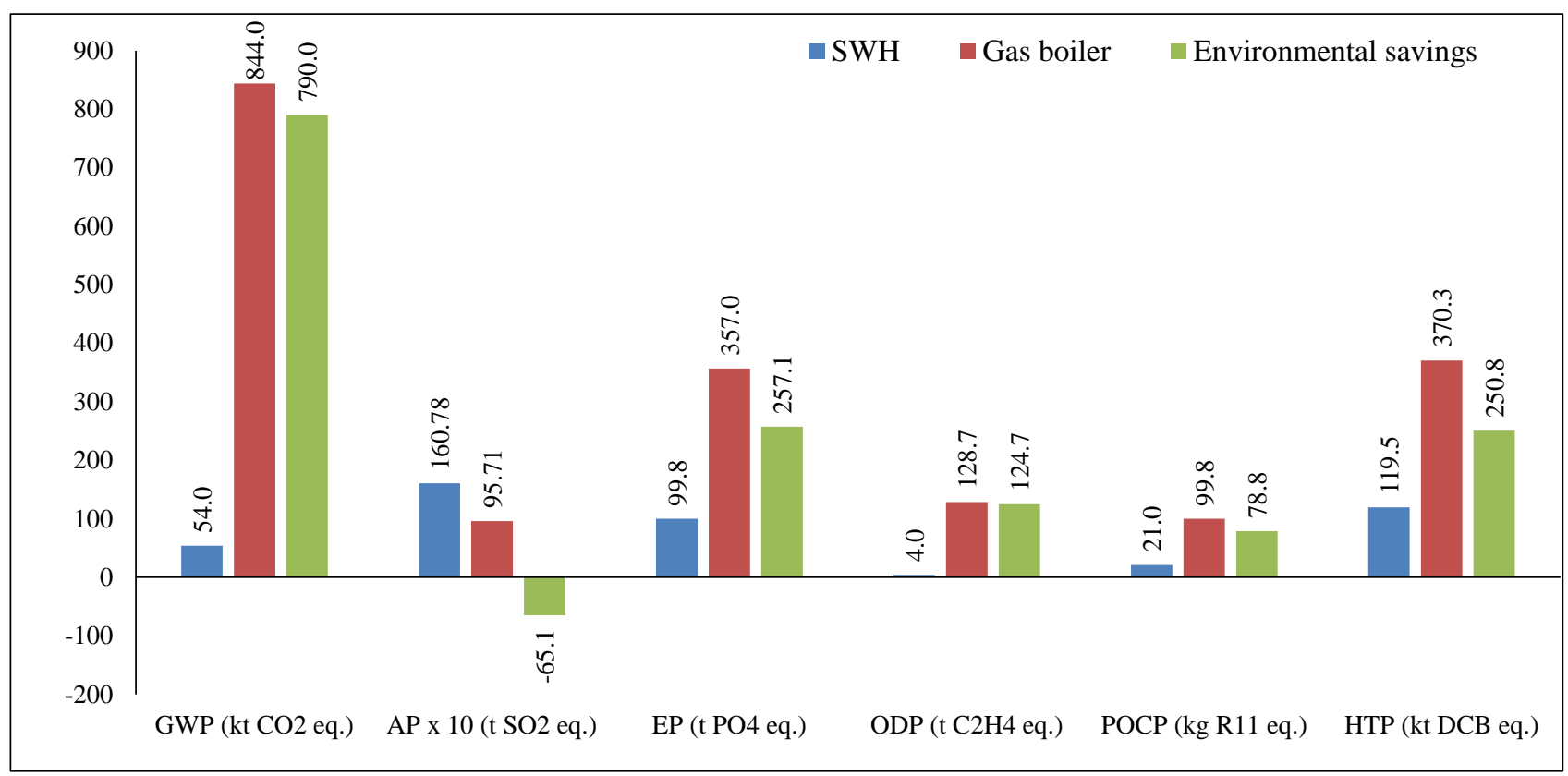

Figure 15. Nation-wide impacts of the utilisation of SWHs in Turkey

[All impacts expressed per functional unit over the lifetime of 25 years. The negative value for AP denotes the increase in the impact. For the impacts nomenclature, see Figure 12.] 
As also shown in Figure 15, significant savings would also be achieved for the other impacts, ranging from three times lower HTP to 32 times lower ODP. The only exception is AP which is by a factor of two higher than that for the gas boiler. As discussed in section 3.3 this is due to high electricity consumption of the heat exchanger pump in colder regions and the high AP in the Turkish electricity mix.

Thus, on balance, it could be argued that the uptake of SWH should be encouraged by government through appropriate incentives. As of late 2017, a typical SWH system with the specifications considered here would cost around 2000 Turkish Liras (€430). Assuming that all the energy saved would otherwise be obtained from a natural gas boiler, the approximate financial payback period of SWH systems in Turkey would range from 16 to 18 years. Given the expected lifetime of 25 years, it can be concluded that the SWH systems are economically feasible. However, offering governmental incentives could easily reduce the payback periods, which would increase the uptake and market penetration of SWH systems. Currently, incentives are available in Turkey only for photovoltaic systems but not SWHs. As Table 6 suggests, there is a particularly high potential for increasing the uptake of SWH in Marmara and Karadeniz regions, where only 5\% of the houses have these systems installed. Despite being in the northern parts of the country with a relatively low solar radiation, almost all of the cities in these regions have the climate of Region 2, which means that the SWH systems are likely to do without an additional heat exchanger, thereby being less costly but also reducing the overall environmental impacts.

\section{Conclusions}

This study analysed the life cycle environmental impacts of solar water heater (SWH) systems for domestic hot water supply in four different climatic regions of Turkey. The results showed that in all four regions, at least $81 \%$ of the annual hot water requirement could be met via the SWH system. The energy output was significantly higher than the input (7-28 times), with the payback periods ranging between one and three years. The findings also suggested that in the hotter regions the impacts of the SWH systems are 1.5-2 times lower than those of natural gas boilers. A similar trend was observed for SWH in the two colder regions except for acidification, which was four times higher than that of the boiler. This was due to the need to use a heat exchanger and the associated electricity for water pumping.

The construction materials and the electricity required for the manufacturing of the systems were the main environmental 'hotspots'. Recycling the major components instead of landfilling reduced human toxicity potential by $50 \%$ but had only a small effect $(5 \%)$ on the other impacts. The impacts were highly sensitive to the type of material used for the construction of the hot storage tank and to some extent to the amount of electricity used by the heat-exchanger pump. Recycling the materials at the end of life did not have an effect on the impacts.

Significant savings in greenhouse gas emissions (8.5-27 times) can be achieved by using SWH instead of gas boilers. At the national level, the $\mathrm{SWH}$ systems can save $790 \mathrm{kt} \mathrm{CO}_{2}$ eq. per year, equivalent to $0.17 \%$ of annual emissions in Turkey. The other impacts would be reduced by three to 32 times. The nation-wide use of SWH would also contribute to the Turkish economy by saving $\$ 162.5$ million per year through the avoided imports of natural gas. Therefore, SWH systems should be deployed more extensively in Turkey, especially in the northern regions of Karadeniz and Marmara. However, government incentives may be needed to stimulate the uptake, similar to those already in existence for solar PV. 


\section{Nomenclature}

ASI average solar irradiation for a given region $\left(\mathrm{kWh} / \mathrm{m}^{2}\right.$.day)

$C_{p, w} \quad$ average specific heat of liquid water $\left(4.18 \mathrm{~kJ} / \mathrm{kg} .{ }^{\circ} \mathrm{C}\right)$

$\mathrm{DH}_{S W H} \quad$ number of detached houses with $\mathrm{SWH}$ systems (-)

OR ownership rate for each region (-)

$P \quad$ total population in each city (-)

$Q_{H W} \quad$ daily energy requirement for the household domestic hot water supply (W)

$Q_{\text {out }} \quad$ energy provided by the SWH system on a daily basis (kWh/day)

$T_{h, o} \quad$ temperature of hot water at the outlet of the collector $\left({ }^{\circ} \mathrm{C}\right)$

$T_{c, i} \quad$ temperature of cold water at the inlet into the collector $\left({ }^{\circ} \mathrm{C}\right)$

$\dot{V}_{H W} \quad$ daily requirement of domestic hot water (100 1/day).

Greek symbols:

$\rho_{w} \quad$ average density of liquid water $\left(1000 \mathrm{~kg} / \mathrm{m}^{3}\right)$.

\section{References}

Abuska, M., 2012. Solar Energy Applications in Turkey (in Turkish). [Online] Available at: akhisarmyo.cbu.edu.tr/db_images/file/gunes-enerjisi-3-1285TR.pdf [Accessed 2510 2016].

Achintha, M., 2016. Sustainability of Glass in Construction. In: J. Khatib, ed. Sustainability of Construction Materials, 2nd ed.. United Kingdom: Woodhead Publishing, pp. 79-104.

Al-Madani, H., 2006. The performance of a cylindrical solar water heater. Renewable Energy, 31(11), p. 1751-1763.

Altuntop, N. \& Erdemir, D., 2012. Investigating the Development of Solar Energy Systems Market in Turkey. Istanbul, IRENEC 2012.

Altuntop, N. \& Erdemir, D., 2013. Development of the Solar Energy in Turkey and Around the World. Mühendis ve Makina, 54(639), pp. 69-77.

Anon., 2009. Türk Halkı Sitede Oturmak Istemiyor (in Turkish). [Online] Available at: http://www.yapi.com.tr/haberler/turk-halki-sitede-oturmayi-istemiyor_66021.html [Accessed 211 2016].

Anon., 2014. Family Statistics (in Turkish). [Online]

Available at: http://www.tuik.gov.tr/PreHaberBultenleri.do?id=18624

[Accessed 2410 2016].

Anon., 2016. Carbon Markets. [Online]

Available at: http://turkishcarbonmarket.com/carbon-markets

[Accessed 2710 2016]. 
Ardente, F., Beccali, G., Cellura, M. \& Lo Brano, V., 2005. Life cycle assessment of a solar thermal collector: sensitivity analysis, energy and environmental balances. Renewable Energy, Volume 30, pp. 109-130.

Atilgan, B. \& Azapagic, A., 2015. Life cycle environmental impacts of electricity from fossil fuels in Turkey. Journal of Cleaner Production, Volume 106, pp. 555-564.

Atilgan, B. \& Azapagic, A., 2016. An integrated life cycl esustainability assessment of electricity generation in Turkey. Energy Policy, Volume 93, pp. 168-186.

Barnes, E. \& Parrish, K., 2016. Small buildings, big impacts: The role of small commercial building energy efficiency case studies in 2030 Districts. Sustainable Cities and Society, Volume 27, pp. 210221.

Beccali, M. et al., 2012. Life Cycle Assessment Performance Comparison of Small Solar Thermal Cooling Systems with Conventional Plants Assisted with Photovoltaics. Energy Procedia, Volume 30, pp. 893-903.

Beccali, M. et al., 2014. Life cycle performance assessment of small solar thermal cooling systems and conventional plants assisted with photovoltaics. Solar Energy, Volume 104, pp. 93-102.

Beccali, M., Cellura, M., Longo, S. \& Guarino, F., 2016. Solar heating and cooling systems versus conventional systems assisted by photovoltaic: Application of a simplified LCA tool. Solar Energy Materials and Solar Cells, Volume 156, pp. 92-100.

Beccali, M., Cellura, M., Longo, S. \& Mugnier, D., 2016. A simplified LCA tool for solar heating and cooling systems. Energy Procedia, Volume 91, pp. 317-324.

Beccali, M. et al., 2012. LCA of a solar heating and cooling system equipped with a small waterammonia absorption chiller. Solar Energy, Volume 86, pp. 1491-1503.

Benli, H., 2016. Potential application of solar water heaters for hot water production in Turkey. Renewable and Sustainable Energy Reviews, Volume 54, pp. 99-109.

Canel, M., Misirlioglu, Z., Canel, E. \& Acar Bozkurt, P., 2016. Distribution and comparing of volatile products during slow pyrolysis and hydropyrolysis of Turkish lignites. Fuel, Volume 186, pp. 504-517.

Cao, X., Dai, X. \& Liu, J., 2016. Building energy-consumption status worldwide and the state-ofthe-art technologies for zero-energy buildings during the past decade. Energy and Buildings, Volume 128, pp. 198-213.

CCalC, 2016. CCalC Software and Database. [Online]

Available at: www.ccalc.org.uk

[Accessed 1810 2016]. 
Chen, Z. et al., 2012. Efficiencies of flat plate solar collectors at different flow rates. Energy Procedia, Volume 30, pp. 65-72.

Cift, B. \& Okutan, H., 2010. Baca gazı desülfürizasyon proseslerinin ekonomik ve teknik analizi. ITU Dergisi/D Muhendislik (in Turkish), 9(4), pp. 85-96 .

CleaverBrooks, 2010. Boiler Efficiency Guide. [Online]

Available at: http://www.which.co.uk/reviews/boilers/article/boiler-energy-efficiency

[Accessed 255 2017].

Demirdöküm, 2010. Bozüyük Facilities (in Turkish). [Online]

Available at: http://www.demirdokum.com.tr/kurumsal/demirdokum-hakk-nda/bozuyuk-

tesisleri/index.tr_tr.html

[Accessed 1910 2016].

Demirdöküm, 2013. Lykia System Assembly Guide (in Turkish). [Online]

Available at: http://www.demirdokum.com.tr/products-2/sertifikalar-guencel/lykia-sistem-manual475475.pdf

[Accessed 1810 2016].

Ecoinvent, 2017. Ecoinvent.org. [Online]

Available at: http://www.ecoinvent.org

[Accessed 189 2017].

Ekici, B., A.A, G. \& Aksoy, U., 2012. A study on the optimum insulation thicknesses of various types of external walls with respect to different materials, fuels and climate zones in Turkey.

Applied Energy, Volume 92, pp. 211-217.

EngineeringToolbox.com, undated. Metals and Alloys - Densities. [Online]

Available at: http://www.engineeringtoolbox.com/metal-alloys-densities-d_50.html

[Accessed 311 2016].

EngineeringToolbox, undated. Fuel Gases' Heating Values. [Online]

Available at: http://www.engineeringtoolbox.com/heating-values-fuel-gases-d_823.html

[Accessed 66 2017].

EU Energy Commission, 2015. 2014 Country Reports: Greece. [Online]

Available at: https://ec.europa.eu/energy/sites/ener/files/documents/2014_countryreports_greece.pdf [Accessed 305 2017].

European Commission, 2004. Materials Used for Manufacturing Domestic Hot Water Systems \& Comments on Their Reliability. [Online]

Available at: http://exergia.gr/wp-content/uploads/materials-domestic-water.pdf

[Accessed 311 2016]. 
Finocchiaro, P. et al., 2016. Life Cycle Assessment of a compact Desiccant Evaporative Cooling system: The case study of the "Freescoo". Solar Energy Materials \& Solar Cells, Volume 156, pp. 83-91.

Florida Solar Energy Center, 2015. Estimating Daily Domestic Hot Water Water Use in North American Homes. [Online]

Available at: http://www.fsec.ucf.edu/en/publications/pdf/FSEC-PF-464-15.pdf

[Accessed 255 2017].

Glass Packacing Institute, 2010. Environmental Overview: Complete Life Cycle Assessment of North American Container Glass, California, USA: s.n.

Greening, B. \& Azapagic, A., 2014. Domestic solar thermal water heating: A sustainable option for the UK. Renewable Energy, Volume 63, pp. 23-36.

Guinee, J. et al., 2001. Life Cycle Assessment, an Operational Guide to the ISO Standards. Part 2a: Guide, Dordrecht, The Netherlands: Kluwer Academic Publishers.

Hang, Y., Qu, M. \& Zhao, F., 2012. Economic and environmental life cycle analysis of solar hot water systems in the United States. Energy and Buildings, Volume 45, pp. 181-188.

Harvey, L., 2009. Reducing energy use in the buildings sector: measures, costs, and examples. Energy Efficiency, 2(2), pp. 139-163.

IEA, 2013a. Transition to Sustainable Buildings: Strategies and Opportunities to 2050. [Online] Available at: http://www.iea.org/etp/buildings/

[Accessed 1710 2016].

IEA, 2013b. Oil and Gas Security - Emergency Response of IEA Countries: Turkey. [Online] Available at:

https://www.iea.org/publications/freepublications/publication/2013_Turkey_Country_Chapterfinal_ with_last_page.pdf

[Accessed 1810 2016].

IEA, 2014. Solar Heat Worldwide. [Online]

Available at: http://www.iea-shc.org/solar-heat-worldwide

[Accessed 1710 2016].

Incecik, S., 2015. Dünyada ve Türkiye de Enerji Görünümü (in Turkish). Istanbul, Electrical \& Electronics Engineering Conference.

International Energy Agency, 2013. Transition to Sustainable Buildings: Strategies and Opportunities to 2050, Paris, France: IEA.

ISO, 2006a. ISO 14040-Environmental management - life cycle assessment - principles and framework, Geneva: International Standards Organization (ISO). 
ISO, 2006b. ISO 14044 - Environmental management - life cycle assessment - requirements and guidelines, Geneva: International Standards Organization.

Jamar, A., Majid, Z. A. W., Norhafana, M. \& Razak, A., 2016. A review of water heating system for solar energy applications. International Communications in Heat and Mass Transfer, Volume 76, pp. 178-187.

Johnson, A., Gutierrez, M., Gouzie, D. \& McAliley, L., 2016. State of remediation and metal toxicity in the Tri-State Mining District, USA. Chemosphere, Volume 144, pp. 1132-1141.

Johnson, A., Gutiérrez, M., Gouzie, D. \& McAliley, L., 2016. State of remediation and metal toxicity in the Tri-State Mining District, USA. Chemosphere, Volume 144, pp. 1132-1141.

Koktuk, tarih yok Sıhhi Tesisat Tekniğinde Su Tüketimi Hesabı (in Turkish). [Çevrimiçi].

Kokturk, U., 2008. Sıhhı Tesisat Tekniğinde Su Tüketimi Hesabı (in Turkish). [Online] Available at: http://www.mmo.org.tr/resimler/dosya_ekler/ed33392d3a48aa1_ek.pdf?dergi [Accessed 1810 2016].

Koroneos, C. \& Nanaki, E., 2012. Life cycle environmental impact assessment of a solar water heater. Journal of Cleaner Production, Volume 37, pp. 154-161.

Lamnatou, C., Notton, G., Chemisana, D. \& Cristofari, C., 2015. The environmental performance of a building-integrated solar thermal collector, based on multiple approaches and life-cycle impact assessment methodologies. Building and Environment, Volume 87, pp. 45-58.

Longo, S. et al., 2017. Energy balance and life cycle assessment of small size residential solar heating and cooling systems equipped with adsorption chillers. Solar Energy, Volume 158, pp. 543558.

Muneer, T., Asif, M., Cizmecioglu, Z. \& Ozturk, H., 2008. Prospects for solar water heating within Turkish textile industry. Renewable and Sustainable Energy Reviews, Volume 12, pp. 807-823.

Paraskevas, D., Kellens, K., Dewulf, W. \& Duflou, J., 2015. Environmental modelling of aluminium recycling: a Life Cycle Assessment tool for sustainable metal management. Journal of Cleaner Production, Volume 105, pp. 357-370.

Republic of Turkey - Ministry of Foreign Affairs, 2016. Turkey's Energy Profile and Strategy. [Online]

Available at: http://www.mfa.gov.tr/turkeys-energy-strategy.en.mfa [Accessed 1810 2016].

Ripa, M., Fiorentino, G., Vacca, V. \& Ulgiati, S., 2016. The relevance of site-specific data in Life Cycle Assessment (LCA). The case of the municipal solid waste management in the metropolitan city of Naples (Italy). Journal of Cleaner Production (article in press) http://dx.doi.org/10.1016/. 
Simons, A. \& Firth, S., 2011. Life-cycle assessment of a 100\% solar fraction thermal supply to a European apartment building using water-based sensible heat storage. Energy and Buildings, Volume 43, pp. 1231-1240.

Squadrone, S. et al., 2016. Human exposure to metals due to consumption of fish from an artificial lake basin close to an active mining area in Katanga (D.R. Congo). Science of The Total Environment, Volume 568, pp. 679-684.

Tsilingiridis, G., Martinopoulos, G. \& Kyriakis, N., 2004. Life cycle environmental impact of a thermosyphonic domestic solar hot water system in comparison with electrical and gas water heating. Renewable Energy, 29(8), pp. 1277-1288.

Turkish Institute of Statistics, 2015. Greenhouse Gas Emission Inventory of Turkey (in Turkish). [Online]

Available at: http://www.tuik.gov.tr/PreHaberBultenleri.do?id=18744

[Accessed 211 2016].

Turkish Institute of Statistics, 2016. Population of Turkish cities with respect to year (in Turkish). [Online]

Available at: http://www.tuik.gov.tr/PreIstatistikTablo.do?istab_id=1590

[Accessed 211 2016].

Turkyilmaz, O., 2015. Ocak 2015 Itibarlyla Türkiye'nin Enerji Görünümü Raporu (in Turkish), Istanbul: Union of Chambers of Turkish Engineers and Architects.

TÜV, 2013. Reliability, safety and thermal Performance of a thermal solar system. [Online] Available at: http://www.demirdokum.com.tr/products-2/demir-doekuem-ueruenler/guene-enerjisisistemleri-1/guene-enerjisi-paket-sistemleri-1/tuvsolar-sistem-test-raporu-475478.pdf [Accessed 1810 2016].

Ucar, A., 2010. Thermoeconomic analysis method for optimization of insulation thickness for the four different climatic regions of Turkey. Energy, 35(4), pp. 1854-1864.

Üçtuğ, F., 2017. Stakeholder opinion-based comparison of life cycle environmental impacts of electricity generation in Turkey with selected European countries. Anadolu University Journal of Science and Technology A-Applied Sciences and Engineering, 18(1), pp. 178-198.

USDoE, 2011. Building Energy Data Book 2011, s.1.: U.S. Department of Energy.

Vignali, G., 2017. Environmental assessment of domestic boilers: A comparison of condensing and traditional technology using life cycle assessment methodology. Journal of Cleaner Production, Volume 142, pp. 2493-2508.

Viridian Solar, 2016. A Guide to Solar Energy. [Online] Available at: http://www.viridiansolar.co.uk/Solar_Energy_Guide_3_3.htm [Accessed 2510 2016]. 
Vossberg, C., Mason-Jones, K. \& Cohen, B., 2014. An energetic life cycle assessment of C\&D waste and container glass recycling in Cape Town, South Africa. Resources, Conservation and Recycling, Volume 88, pp. 39-49.

WEC, 2009. Solar Energy in the World and in Turkey, Ankara: World Energy Council - Turkish National Committee.

World Steel Association, 2011. Life Cycle Assessment Methodology Report, Brussels, Belgium: s.n. 